\title{
HIV-Specific Antibody Responses in HIV-Infected Patients: From a Monoclonal to a Polyclonal View
}

\author{
Daniela Gallerano ${ }^{a}$ Clarissa R. Cabauatan ${ }^{a}$ Elopy N. Sibanda ${ }^{b}$ Rudolf Valenta ${ }^{a}$ \\ ${ }^{a}$ Division of Immunopathology, Department of Pathophysiology and Allergy Research, Medical University of \\ Vienna, Vienna, Austria; ${ }^{\mathrm{b}}$ Asthma, Allergy and Immune Dysfunction Clinic, Parirenyatwa University Teaching \\ Hospital, Harare, Zimbabwe
}

\section{Key Words}

HIV · Humoral response · Antibody · Peptides · Recombinant proteins $\cdot$ Immunoassay $\cdot$ Microarray

\begin{abstract}
HIV infections represent a major global health threat, affecting more than 35 million individuals worldwide. High infection rates and problems associated with lifelong antiretroviral treatment emphasize the need for the development of prophylactic and therapeutic immune intervention strategies. It is conceivable that insights for the design of new immunogens capable of eliciting protective immune responses may come from the analysis of HIV-specific antibody responses in infected patients. Using sophisticated technologies, several monoclonal neutralizing antibodies were isolated from HIVinfected individuals. However, the majority of polyclonal antibody responses found in infected patients are nonneutralizing. Comprehensive analyses of the molecular targets of HIV-specific antibody responses identified that during natural infection antibodies are mainly misdirected towards gp120 epitopes outside of the CD4-binding site and against regions and proteins that are not exposed on the surface of the virus. We therefore argue that vaccines aiming to induce protective responses should include engineered immunogens, which are capable of focusing the immune response towards protective epitopes.

(c) 2015 S. Karger AG, Basel
\end{abstract}

(C) 2015 S. Karger AG, Basel

$1018-2438 / 15 / 1674-0223 \$ 39.50 / 0$

\section{Introduction}

The analysis of HIV-specific antibody responses started with the discovery of the virus and advanced through several technological developments [1-3]. Figure 1 summarizes research findings made through a variety of techniques in the form of a time line. Studies providing insights into the structure of the envelope (Env) spikes also contributed to the elucidation of HIV-specific antibody responses (fig. 1). The Env spikes represent the HIV surface antigens and are constituted by three pairs of gp 120 and gp41 proteins [4]. The resolution of the structure of the complete trimer was hindered mainly by the fact that the protein is highly glycosylated and carries variable regions that are structurally unstable [5-7]. Solving the structure of the deglycosylated gp120 core (i.e. deleted of variable regions) and of gp120 variants bound to human monoclonal antibodies resulted in the identification of antibody-binding sites and classification of Env epitopes [6-10]. The subsequent development of cryo-electron microscopy tomography for the first time enabled the visualization of Env spikes in their 3D form on the surface of viral particles $[11,12]$. In parallel, techniques for the isolation of human monoclonal antibodies progressed and expanded the panel of available broadly neutralizing antibodies (bNAb) [13-16]. With the conclusion of the first HIV vaccine trial showing some efficacy, many stud-

\section{KARGER 125}

E-Mail karger@karger.com www.karger.com/iaa
Correspondence to: Dr. Daniela Gallerano

Division of Immunopathology, Department of Pathophysiology and Allergy Research Medical University of Vienna

Währinger Gürtel 18-20, 3Q, AT-1090 Vienna (Austria)

E-Mail daniela.gallerano@ meduniwien.ac.at 


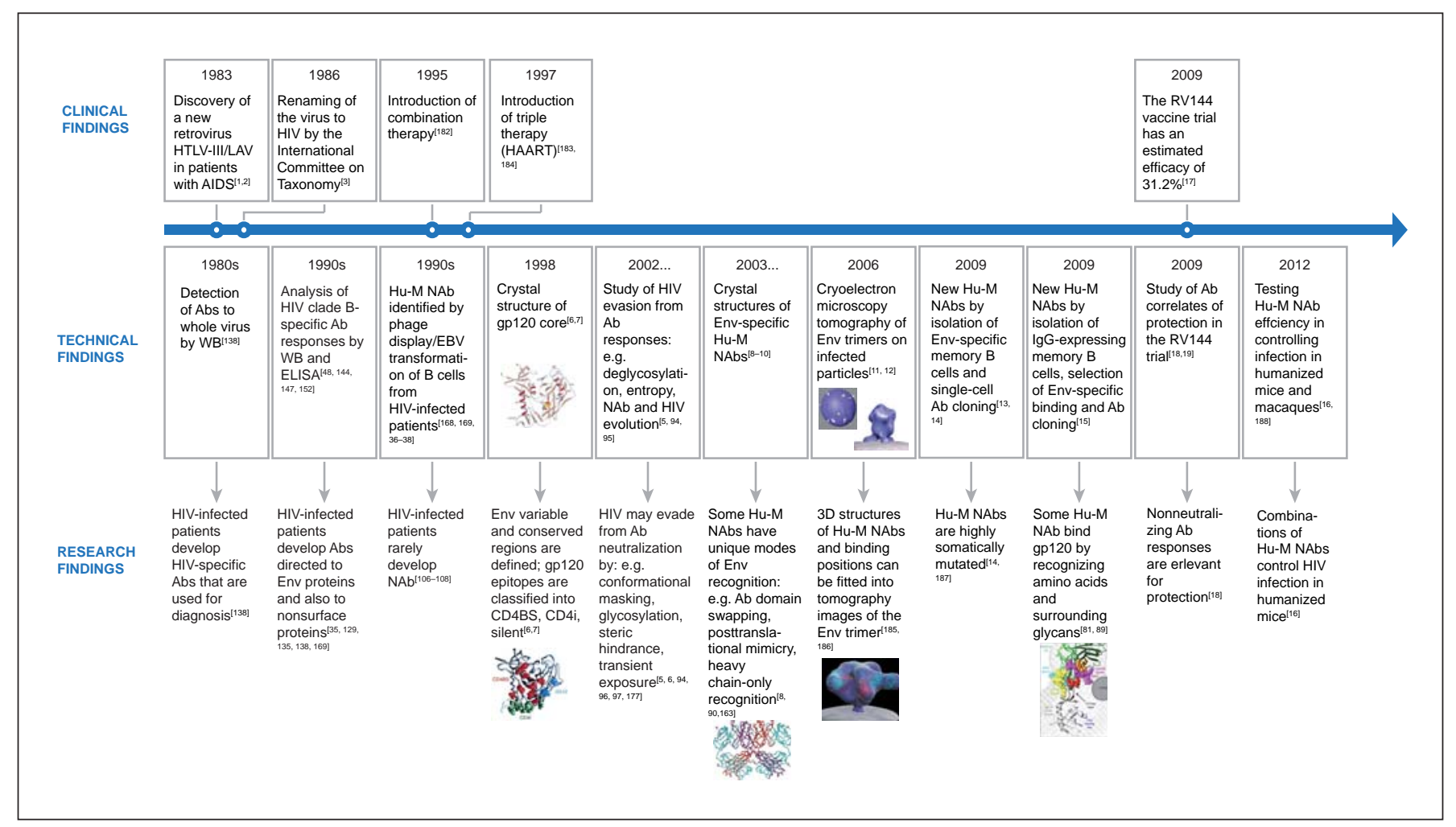

Fig. 1. Time-line showing advances in the study of HIV-specific antibody responses. Selected advances regarding clinical, technical and research findings are displayed. Ab = Antibody; HAART = highly active antiretroviral treatment; $\mathrm{Hu}-\mathrm{M} \mathrm{NAb}=$ human monoclonal neutralizing antibody; EBV = Epstein-Barr virus; WB = Western blot.

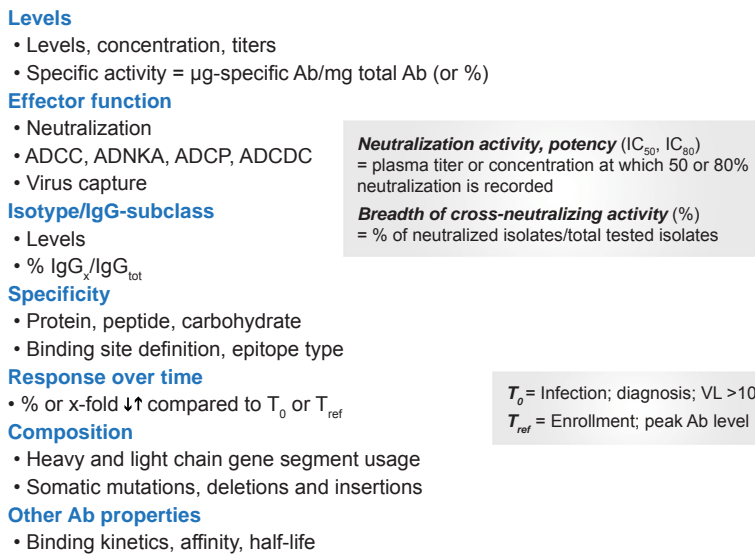

Fig. 2. Characteristics of HIV-specific antibody responses. Ab = Antibody; ADCC = antibody-dependent cellular cytotoxicity; ADCDC = antibody-dependent complement-dependent cytotoxicity; $\mathrm{ADCP}=$ antibody-dependent cellular phagocytosis; ADNKA = antibody-dependent NK cell activation; IC = inhibitory concentration; $\mathrm{T}_{0}=$ initial time point; $\mathrm{T}_{\text {ref }}=$ reference time point; $\mathrm{VL}=$ viral load; $\downarrow=$ decrease; $\uparrow=$ increase. ies focused on the elucidation of the immunological mechanisms associated with the observed effect [17-19]. The finding that nonneutralizing antibodies had a protective role in vaccinated individuals also redirected research efforts towards a better understanding of antibody effector functions that do not involve direct HIV neutralization [18].

HIV-specific antibody responses are studied according to several features of the antibodies, such as function, isotype, specificity and composition (fig. 2). Useful resources are also offered by online databases containing information regarding HIV sequences and features of human monoclonal antibodies (fig. 3). Among the properties that are used to characterize antibody responses, this review focuses on the specificity and isotype/IgG subclass of HIV-specific antibodies.

The specificity of antibody response can be studied at the proteome level (i.e. which HIV proteins elicit antibody responses?) and at the epitope level (i.e. which sites of a protein are bound by the antibody?). The HIV proteome is constituted of several proteins, including Env, 
Fig. 3. Online resources for the study of $\mathrm{HIV}$-specific antibody responses. $\mathrm{Ab}=$ Antibody; bNAb = broadly neutralizing antibody; IC = inhibitory concentration; $\mathrm{NAb}=$ neutralizing antibody.
HIV Sequence Database: http://www.hiv.lanl.gov/

- HIV sequence search per clade, virus isolate, protein, etc.

HIV Molecular Immunology Database: http://www.hiv.lanl.gov/content/immunology/

- Ab search per name of protein, epitope, isotype, etc.

- Tables of NAbs and epitopes

- Standardized protocols for the study of NAbs

Broadly Neutralizing Antibodies Electronic Resource: http://bnaber.org/

- bNAb search per name, $I C_{50}, I_{80}$ breadth, depth

- bNAb sequence characteristics (e.g. somatic mutations, putative genes)

- Links to 3D structures per bNAb

Electron Microscopy Data Bank: http://www.ebi.ac.uk/pdbe/emdb/searchResults.html/?q=hiv *

- EM images of HIV particles, HIV proteins, HIV Env in complex with Abs

- EM search per name, author, resolution, etc. structural, functional and accessory proteins [20]. In mature HIV particles, Env proteins protrude from the lipidic Env membrane, matrix proteins (p17) are associated with the inner lipid layer and capsid proteins (p24) form a conical shell enclosing the viral RNA, RNA-associated nucleocapsid multimers (p7) and other viral components [21]. Functional proteins encoded by the pol gene are mainly responsible for reverse transcription (reverse transcriptase + RNAse, p66), integration (integrase, p31) and maturation (protease, PR). Accessory proteins are involved in protein expression (Rev and Tat), immunopathogenesis and immune evasion (Nef, Vif, Vpr, Vpu) [20].

Analyzing the type and targets of HIV-specific antibody responses may therefore help to understand why the majority of HIV-infected patients are unable to control infection despite the presence of high antibody levels. Indeed, it was recently described that HIV-1 controllers had increased antibody effector functions that were associated with certain specificities and subclass profiles [22]. The development of multiplex immunoassays, such as antigen microarrays, is currently opening the field for a broad and systematic subclass and specificity profiling that could be useful for the identification of antibody signatures associated with certain clinical or biological outcomes [23-27]. This review will summarize the technologies used to study the isotype and specificity of HIV-specific antibody responses, the time course of antibody responses arising during early infection, antibody responses found in diverse body fluids, and the molecular targets and isotype/subclass distribution of Env- and non-Env-specific antibodies found in $\mathrm{HIV}$-infected patients.

HIV-Specific Antibodies - Isotypes and Specificity

\section{Analysis of Isotypes, Functions and Specificities of HIV-Specific Antibody Responses}

The specificities, functions and isotypes/subclasses of antibody responses elicited during HIV infection can be studied by several methods (table 1). In fact, besides techniques that can be applied for the study of antibody responses in terms of simple binding to the antigen/epitope, there are also techniques that allow studying certain functions of the antibodies, such as neutralization, complement activation and antibody-dependent cellular cytotoxicity [14, 28-34]. In addition, several techniques were developed to generate monoclonal antibodies and to study immune complexes (e.g. virion-bound antibodies) as well as antibody-secreting cells [14, 35-44]. For example, the neutralizing activity of antibodies and their specificity can be assessed by measuring the neutralization of different Env-pseudotyped viruses, i.e. of viruses expressing different Env proteins, including those of different HIV strains and those mutated at potential antibodybinding sites $[14,35]$. This technique has the advantage of testing the antibody's neutralization effect and its binding towards the Env protein as a 'natural' molecule embedded in a viral membrane.

To analyze the specificity of antibodies, which may exert other effector functions, methods such as ELISA, immunoblotting, customized Luminex binding assays and microarrays are currently used (table 1) [27, 42, 45-48]. These assays are based on the recognition of Fc portions of antibodies present in human samples by labelled secondary antibodies (e.g. anti-human IgG). They therefore allow determinations of antibody isotypes and IgG subclasses specific for the antigens used, which can be pro-

Int Arch Allergy Immunol 2015;167:223-241 225 
Table 1. Methods used to study type, specificity and function of HIV antibody responses

\begin{tabular}{|c|c|c|c|c|c|}
\hline & \multirow{2}{*}{$\begin{array}{l}\text { Method to study Ab type and } \\
\text { specificity }\end{array}$} & \multirow[t]{2}{*}{ Isotype/IgG-subclass } & \multicolumn{2}{|c|}{ Specificity } & \multirow[t]{2}{*}{ Ref. } \\
\hline & & & proteins & peptides $^{1}$ & \\
\hline \multirow[t]{6}{*}{ Study of $\mathrm{Ab}$ responses } & Western blotting, immunoblotting & $\operatorname{IgG}, \operatorname{IgG}_{1-4}, \operatorname{IgM}$ & $\sqrt{ }$ & $\sqrt{ } \sqrt{ }$ & {$[47,51,145,153,156]$} \\
\hline & ELISA & IgG, $\operatorname{IgG}_{1-4}, \operatorname{IgA}, \operatorname{IgM}$ & $\sqrt{ }$ & $\sqrt{ } \sqrt{ }$ & {$[42,45,46,48]$} \\
\hline & Customized Luminex binding assay & IgG, IgA, IgM & $\sqrt{ }$ & $\sqrt{ }$ & {$[42,49]$} \\
\hline & Customized Luminex subclass assay & IgG, $\operatorname{IgG}_{1-4}$ & $\sqrt{ }$ & - & {$[50]$} \\
\hline & Peptide array & IgG & - & $\sqrt{ } \sqrt{ }$ & {$[54]$} \\
\hline & HIV microarray & $\operatorname{IgG}, \operatorname{IgG}_{1-4}, \operatorname{Ig} A, \operatorname{IgM}, \operatorname{IgE}$ & $\sqrt{ }$ & $\sqrt{ } \sqrt{ }$ & {$[27]$} \\
\hline Study of neutralizing Abs & $\begin{array}{l}\text { Neutralization assays with } \\
\text { Env-pseudotyped viruses }\end{array}$ & - & \multicolumn{2}{|c|}{$\begin{array}{l}\text { Env-pseudotyped } \\
\text { viruses }\end{array}$} & {$[14,35]$} \\
\hline \multirow[t]{2}{*}{ Structural studies } & $\begin{array}{l}\text { Crystallization of monoclonal } \\
\text { antibody in complex with antigen }\end{array}$ & - & $\sqrt{ }$ & $\sqrt{ }$ & {$[39,40]$} \\
\hline & $\begin{array}{l}\text { Epitope excision/extraction and } \\
\text { MALDI-TOF }\end{array}$ & - & $\begin{array}{l}\text { Protein } \\
\mathrm{Ab}\end{array}$ & bound to & {$[41]$} \\
\hline \multirow[t]{2}{*}{ Study of virion-bound Abs } & $\begin{array}{l}\text { Virus capture assay with a-huIgG } \\
\text { or a-huIgM }\end{array}$ & IgG, IgM & - & - & {$[42]$} \\
\hline & $\begin{array}{l}\text { Depletion of specific Abs with } \\
\text { Ag-beads and virus capture }\end{array}$ & - & $\sqrt{ }$ & - & {$[43]$} \\
\hline \multirow[t]{2}{*}{$\begin{array}{l}\text { Study of Ab-secreting B cells and } \\
\text { secreted Abs }\end{array}$} & $\begin{array}{l}\text { Integrated single-cell analysis and } \\
\text { microengraving }\end{array}$ & $\operatorname{IgG}_{1}, \operatorname{IgG}_{3}, \operatorname{IgA}_{1 / 2}, \operatorname{IgM}$ & $\sqrt{ }$ & $\sqrt{ }$ & {$[44]$} \\
\hline & \multicolumn{4}{|l|}{ Method to study Ab function } & Ref. \\
\hline Virus neutralization & \multicolumn{4}{|c|}{$\begin{array}{l}\text { Neutralization assay (reduction in luciferase reporter gene expression after } \\
\text { single-round infection of reporter cell lines) }\end{array}$} & {$[35]$} \\
\hline Virus capture & \multicolumn{4}{|c|}{ Virus capture assay; infectious virus capture assay } & {$[28,29,42,43]$} \\
\hline $\begin{array}{l}\text { Ab-dependent complement-dependent } \\
\text { cytotoxicity }\end{array}$ & \multicolumn{4}{|c|}{$\begin{array}{l}\text { Calcein release-based antibody-dependent complement-mediated lysis assay } \\
\text { Complement-dependent microtoxicity assay }\end{array}$} & {$[28-30]$} \\
\hline $\mathrm{ADCC}$ & \multicolumn{4}{|c|}{ ADCC-GranToxiLux assay; rapid fluorometric ADCC assay } & {$[31,32]$} \\
\hline Ab-dependent NK cell activation & \multicolumn{4}{|c|}{ Intracellular cytokine staining; NK cell degranulation } & {$[33]$} \\
\hline Ab-dependent cellular phagocytosis & \multicolumn{4}{|l|}{ THP-1 phagocytosis assay } & {$[34]$} \\
\hline
\end{tabular}

teins, peptides and carbohydrates [42, 48-50]. Mapping the position of linear epitopes on the amino acid sequence of proteins is achieved with panels of synthetic overlapping peptides [46, 48, 51-53]. However, testing the specificity of antibodies against a large number of peptides and proteins with assays such as ELISA is time-consuming and requires large amounts of the samples. This has limited epitope mapping studies and testing for multiple antigens in the past. The development of multiplex technologies such as microarrays has recently overcome these limitations. In fact, an array containing overlapping 15-mers derived from Env proteins of different HIV subtypes was used to map Env-specific IgG responses elicited during vaccine trials and during infection [54]. Because of the in- clusion of peptides from different HIV subtypes, this array can be used to gain information about interclade crossreactivity patterns. Furthermore, we developed an HIV microarray containing recombinant proteins of the HIV1 clade $\mathrm{C}$ proteome and overlapping peptides ( $\geq 25$ amino acids) covering the amino acid sequences of gp120 and gp41 [27]. This array has the advantage that it contains both proteins and peptides, allowing the measurement of antibody levels specific for both conformation-dependent and linear epitopes on one chip. In addition to the detection of human IgG, pilot experiments show that determination of IgG subclasses and isotypes is also possible with this chip [27]. 
Table 2. HIV-specific antibody responses in early infection

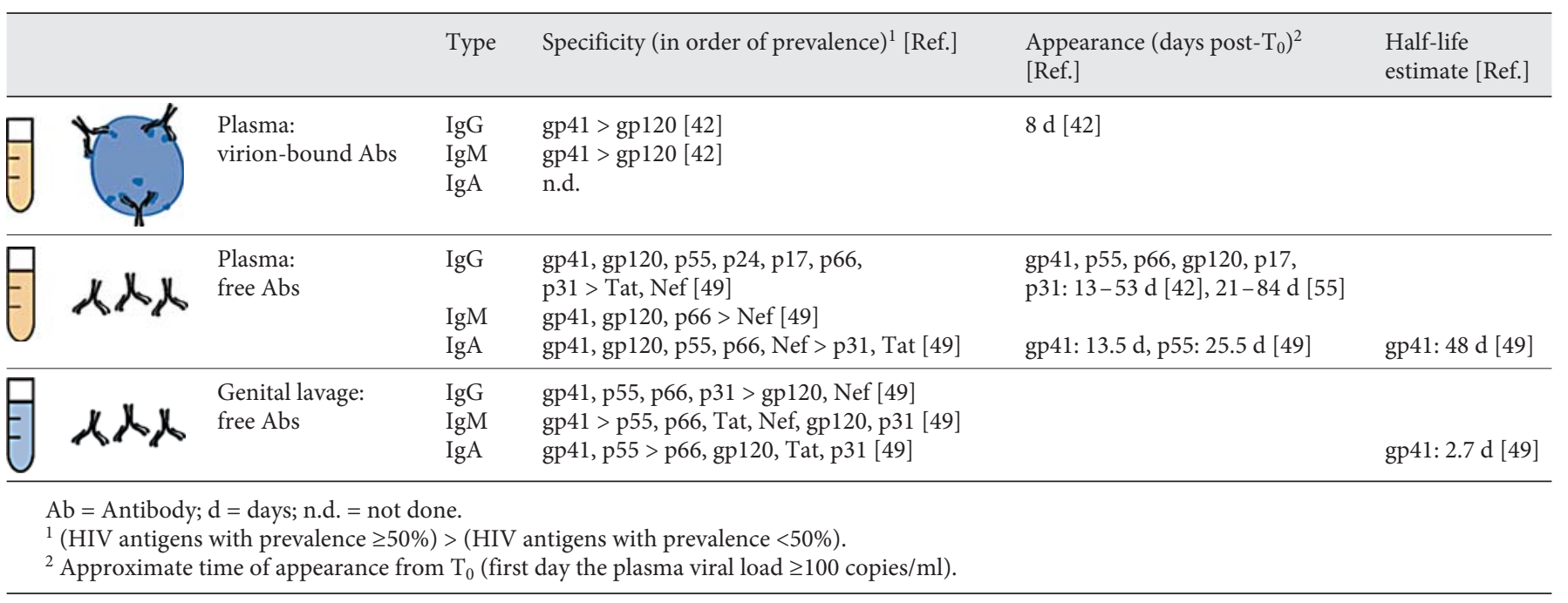

\section{Development of HIV-Specific Antibodies upon Infection: Time Course of Early Responses and Occurrence in Body Fluids}

Studies based on ELISA, multiplex binding assays and virus capture assays with anti-human antibodies analyzed the development of initial antibody responses during acute HIV infection (table 2). The first antibodies were detected in plasma as virion-bound antibodies, 8 days after the plasma viral load was $\geq 100$ copies $/ \mathrm{ml}$. Immune complexes contained IgG and IgM antibodies specific for gp41 and gp120 [42]. Free HIV-specific IgG was first detected in plasma at around 13-53 days and 21-84 days with the sequential appearance of gp41-, p55-, p66-, gp120-, p17- and p31-specific antibodies [42, 55]. The detection of free HIV-specific IgG and IgM in the serum of HIV-infected individuals (i.e. seropositivity) is used as a marker for infection in current HIVdiagnostic tests (i.e. ELISA- and Western blot-based tests) $[56,57]$. A recent study investigating early HIVspecific antibody responses in genital lavage samples pointed out that IgG, IgM and IgA develop early upon infection and are directed towards Env, structural and functional proteins with a predominance of gp41-specific antibodies [49].

In contrast to the rapid development of HIV-specific antibodies, the first neutralization activity was shown for antibodies detected 1-2 and 3 months postinfection in HIV clade B and clade C infections, respectively $[55,58$, 59]. These antibodies neutralized autologous viruses and could induce viral escape mutants [58]. bNAb that also

HIV-Specific Antibodies - Isotypes and Specificity inhibit the infection of heterologous strains are developed by some HIV-infected patients at a later stage of infection $[60,61]$. A recent study showed that bNAb were also found in HIV-infected infants at 11-28 months after infection [62]. The time course of the earliest antibody-mediated immune responses in respect to innate and T cellmediated responses has been reviewed elsewhere [56].

Most of the information regarding HIV-specific antibodies derives from studies focusing on free antibodies found in plasma or serum samples. Some analyses, however, demonstrated that antibodies directed towards several HIV proteins and of different isotypes and IgG subclasses can also be found in body fluids, such as cerebrospinal fluids, saliva and genital secretions (table 3) [49, 63-71]. Further studies are still necessary to clarify to what extent antibodies found at these sites represent a transudate from the blood or are locally produced, and to elucidate their protective role during HIV infections [49, $63,64,66,70-77]$.

\section{Env Spikes as Targets for HIV-Specific Antibodies}

Env proteins certainly represent major molecular targets of HIV-specific antibodies and are of importance for virus neutralization. Images obtained by cryo-electron tomography showed how gp120/gp41 trimers protrude from the viral membrane in the form of spikes ( 4-35 spikes per HIV-1 virion), constituting HIV's surface antigens $[11,78]$. In the study of Env-specific antibody responses, epitopes have been classified according to their 
Table 3. HIV-specific antibody responses in body fluids

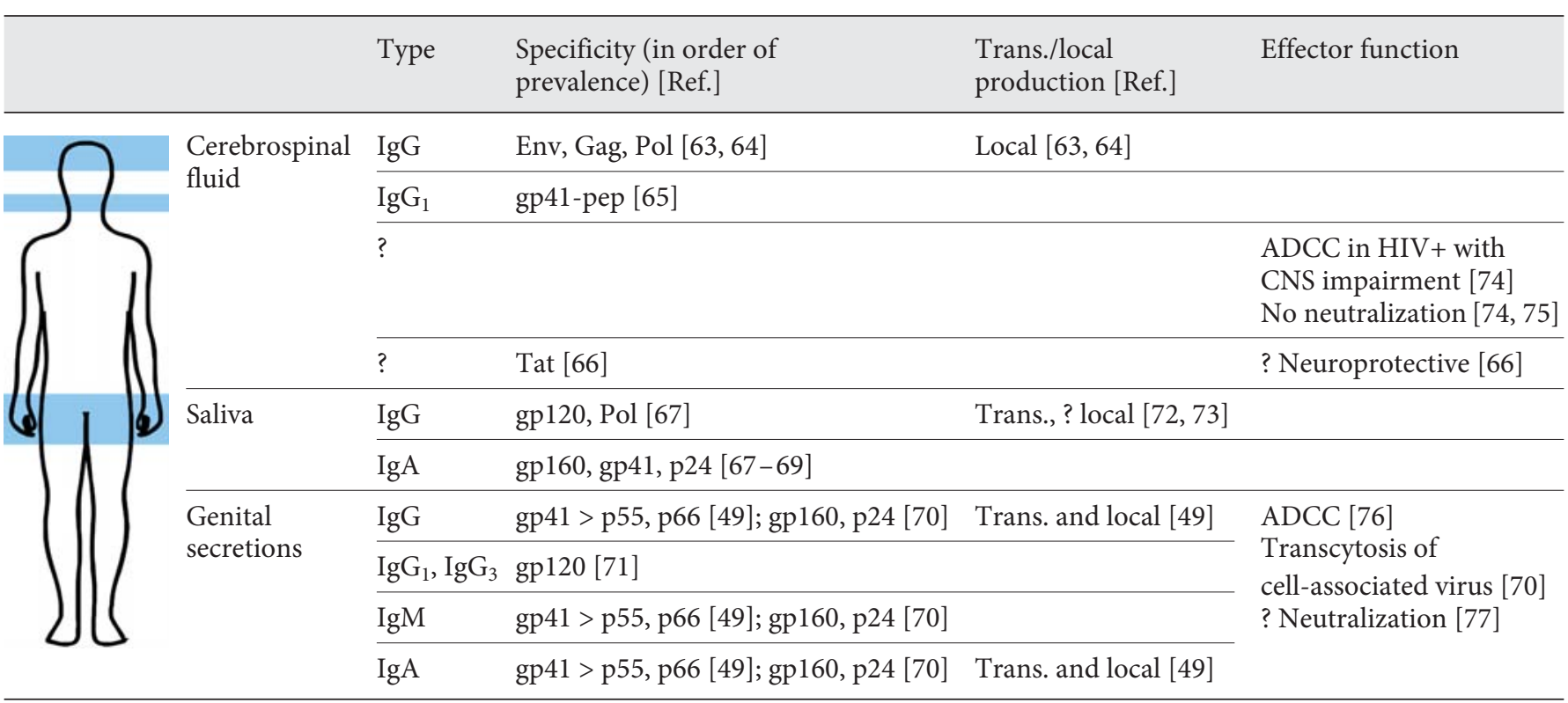

ADCC = Antibody-dependent cellular cytotoxicity; CNS = central nervous system; Trans. = transudation.

Fig. 4. Types of epitopes described for Envspecific antibodies. Classification of epitope types according to the epitope's biochemistry (amino acid residues, glycans), position of residues/glycans constituting the antibody-binding site (linear, discontinuous) and requirements of protein folding or oligomerization (conformational, quaternary). Adapted from Zolla-Pazner and Cardozo [79].

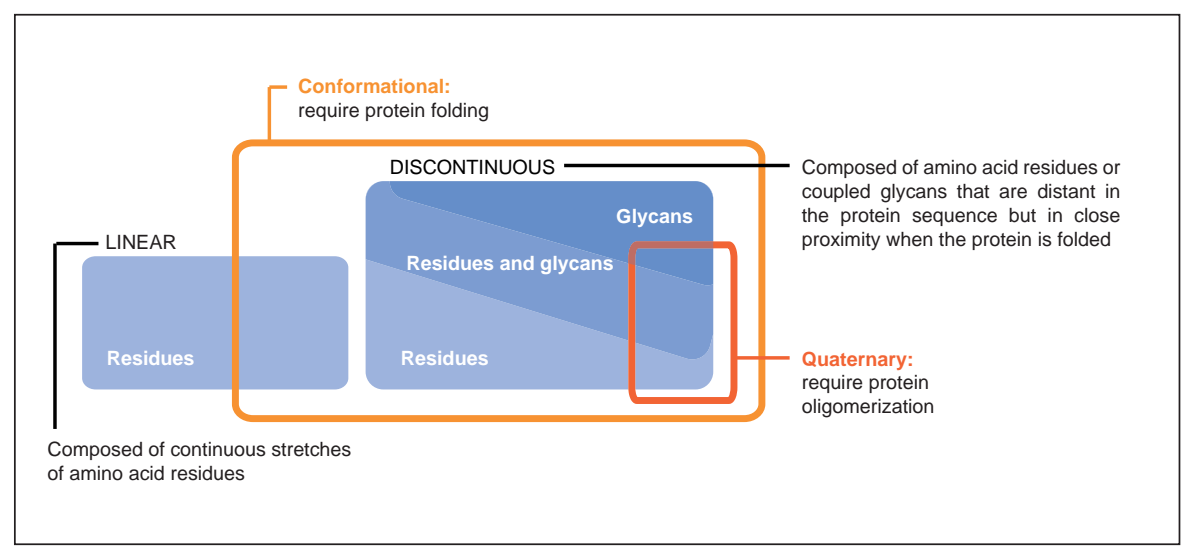

different properties, such as the type and position of the molecules involved in the binding site and the requirement of the intact protein's structure for binding (fig. 4). For example, linear epitopes represent continuous stretches of amino acids and must be distinguished from discontinuous epitopes, which are constituted by portions that are distant in the protein sequence but brought together when the protein is folded. When an epitope is dependent on the structural conformation of the antibody-binding site, it is termed conformational epitope [79]. The structural requirements for antibody binding can even regard not only the protein itself, but also depend on its oligomerization status, such as for quaternary epitopes on Env trimers [80].

\section{Env Epitopes from a Monoclonal View}

The epitopes of Env-specific antibodies have been characterized very well for human monoclonal antibodies isolated/cloned from HIV-infected individuals. Crystallization of antibody-antigen complexes enabled identifying single amino acids and glycans involved in the interaction $[8-10,81,82]$. On the other hand, neutralization 
Table 4. Targets of Env-specific monoclonal antibodies

\begin{tabular}{|c|c|c|c|c|c|c|}
\hline & Epitope ty & ype & $\begin{array}{l}\text { Epitope - involved Env } \\
\text { domains and features }{ }^{1} \\
\text { [Ref.] }\end{array}$ & $\begin{array}{l}\text { Epitope - immune escape } \\
\text { strategies } \\
\text { [Ref.] }\end{array}$ & $\begin{array}{l}\text { Hu-M Abs - } \\
\text { examples with } \\
\text { effector function }{ }^{2}\end{array}$ & Hu-M Abs - features [Ref.] \\
\hline $\begin{array}{l}\text { gp120 } \\
\text { CD4-binding } \\
\text { site }\end{array}$ & $\mathrm{DC}$ & $\mathrm{R}$ & $\begin{array}{l}\mathrm{C} 2, \mathrm{C} 3, \mathrm{C} 4, \mathrm{~V} 5, \mathrm{C} 5[10] \\
\text { target of the majority of } \\
\text { bNAb }\end{array}$ & $\begin{array}{l}\text { Conformational masking by } \\
\text { V1V2 [96, 97] } \\
\text { Glycosylation }[97]\end{array}$ & $\begin{array}{l}\mathrm{b} 12^{\mathrm{bN}, \mathrm{A}}, \mathrm{CH} 103^{\mathrm{bN}}, \\
\mathrm{VRC} 01^{\mathrm{bN}, \mathrm{A}} \\
8 \mathrm{ANC} 131^{\mathrm{bN}} \\
\mathrm{HJ} 16^{\mathrm{bN}}, 3 \mathrm{BCN} 60^{\mathrm{bN}} \\
15 \mathrm{e}^{\mathrm{N}, \mathrm{A}}, \mathrm{F} 105^{\mathrm{N}, \mathrm{A}} \\
448-\mathrm{D}^{\mathrm{N}, \mathrm{A}}, 1125 \mathrm{H}^{\mathrm{N}, \mathrm{A}}\end{array}$ & $\begin{array}{l}\text { Long CDR H3 [101] } \\
\text { CD4 mimicry by VH1-2 [163], } \\
\text { short CDR L3 loops [103] } \\
\text { CD4 mimicry by VH1 -46 [164] } \\
\text { Extensive somatic mutations } \\
\text { [104] } \\
\text { Enhanced flexibility [104] }\end{array}$ \\
\hline $\begin{array}{l}\text { gp120 } \\
\text { CD4-induced } \\
\text { (coreceptor } \\
\text { binding site) }\end{array}$ & $\mathrm{DC}$ & $\mathrm{R}$ & $\begin{array}{l}\mathrm{V} 1-\mathrm{V} 2(\beta 1 \beta 2), \mathrm{V} 3, \mathrm{C} 4 \\
(\beta 20 \beta 21)[6]\end{array}$ & $\begin{array}{l}\text { Conformational masking (exposed } \\
\text { upon gp120-CD4 binding) [6] } \\
\text { Steric hindrance }[94] \\
\text { V2 sulfated Tyr }(173,177)[165]\end{array}$ & $\begin{array}{l}17 \mathrm{~b}^{\mathrm{wN}, \mathrm{A}}, 48 \mathrm{D}^{\mathrm{wN}, \mathrm{A}} \\
412 \mathrm{~d}^{\mathrm{N}}, \mathrm{N} 12-\mathrm{i} 3^{\mathrm{A}} \\
\mathrm{N} 12-\mathrm{il}^{\mathrm{A}}\end{array}$ & $\begin{array}{l}\text { CCR5 mimicry by extended } \\
\text { CDR H3 with sulfated Tyr or } \\
\text { multiple Asp/Glu(-) [9] } \\
\text { Multiple } V_{H} \text { replacement [166] }\end{array}$ \\
\hline $\begin{array}{l}\text { gp120 V3 } \\
\text { loop }\end{array}$ & L C & $\mathrm{R}$ & $\begin{array}{l}306-319[85,86], \\
\text { coreceptor binding, } \\
\text { 'structurally conserved' } \\
{[40]}\end{array}$ & $\begin{array}{l}\text { Mutation, clustered into regions } \\
{[40]} \\
\text { Conformational masking by V1V2 } \\
\text { [97] } \\
\text { Glycosylation [97] }\end{array}$ & $\begin{array}{l}447 / 52-D^{N, A}, 19 b^{w N} \\
694 / 98 D^{N, A}, 2182^{N} \\
4117 C^{N, A}, \\
41148 D^{N, A}\end{array}$ & $\begin{array}{l}\text { Preferential VH5-51 gene usage } \\
\text { [167] }\end{array}$ \\
\hline $\begin{array}{l}\text { gp } 120 \mathrm{~V} 1 \mathrm{~V} 2 \text {, } \\
\text { V3 crown } \\
\text { and glycans }\end{array}$ & $\mathrm{D} C \mathrm{C}$ & RG & $\begin{array}{l}\text { V1V2, V3 crown, } \\
\text { V2-glyc (N160) [82] }\end{array}$ & $\begin{array}{l}\text { Mutation } \\
\text { Glycan type [100] } \\
\text { Glu(-) 168-171 [168] }\end{array}$ & $\begin{array}{l}\text { PG9 } 9^{\mathrm{bN}, \mathrm{A}}, \mathrm{PG} 16^{\mathrm{N}} \\
2909^{\mathrm{N}}, \mathrm{CH} 01-04^{\mathrm{bN}} \\
\text { PGT141-145 }\end{array}$ & $\begin{array}{l}\text { Long CDR H3, often sulfated } \\
\text { Tyr }[80,82]\end{array}$ \\
\hline $\begin{array}{l}\text { gp120 V3 } \\
\text { and glycans }\end{array}$ & $\mathrm{DC}$ & RG & $\begin{array}{l}\text { a) V3, V3-glyc: N301, } \\
\text { N332 [81] } \\
\text { b) V3, V1V2-glyc: N137, } \\
\text { V3-glyc: N332, N301 [89] } \\
\text { c) V3, V4, V3-glyc: N332, } \\
\text { V4-glyc: N392, N386 [39] }\end{array}$ & Mutation [98] & 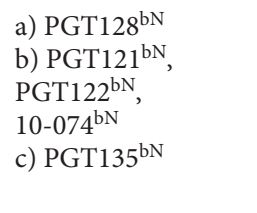 & $\begin{array}{l}\text { Penetration of glycan shield by } \\
\text { extended CDR H3, CDR H2 } \\
\text { insertion [81] } \\
\text { Multiple } V_{H} \text { replacement [166] }\end{array}$ \\
\hline $\begin{array}{l}\text { gp120 inner } \\
\text { domain and } \\
\text { glycans }\end{array}$ & $\mathrm{D} C$ ? & RG & $\begin{array}{l}\text { Inner domain, C2, C3, } \\
\text { V5, C2-glyc: N234, N276, } \\
\text { ? gp41-residues and } \\
\text { gp41-glyc: N637 } 390]\end{array}$ & n.a. & $8 \mathrm{ANC} 195^{\mathrm{bN}}$ & $\begin{array}{l}\text { Heavy chain-only contact to } \\
\text { gp120 [90] } \\
\text { Light chain contact to gp } 41^{3} \text { [90] }\end{array}$ \\
\hline $\begin{array}{l}\text { gp120 } \\
\text { C5 region }\end{array}$ & $\begin{array}{ll}\mathrm{L} & \\
\mathrm{L} & \mathrm{C} \\
\mathrm{D} & \mathrm{C}\end{array}$ & $\begin{array}{l}\mathrm{R} \\
\mathrm{R} \\
\mathrm{R}\end{array}$ & $\begin{array}{l}\text { a) } 491-500[169] \\
\text { b) } 498-504[170] \\
\text { c) } 1489, \text { E509 [41] }\end{array}$ & n.a. & $\begin{array}{l}\text { a) } 42 \mathrm{~F}^{\mathrm{A}}, 43 \mathrm{~F}^{\mathrm{A}} \\
\text { b) } 670-\mathrm{D}^{\mathrm{A}} \\
\text { c) } 1331 \mathrm{~A}^{\text {n.a. }}\end{array}$ & n.a. \\
\hline $\begin{array}{l}\text { gp120 } \\
\text { glycan only }\end{array}$ & $\mathrm{DC}$ & G & $\begin{array}{l}\text { C2-,C3-,V4-glyc: N295, } \\
\text { N332, N339, N392 [8] }\end{array}$ & Mutation [99] & $2 \mathrm{G} 12^{\mathrm{bN}, \mathrm{A}}$ & Domain-swapped Fabs [8] \\
\hline $\begin{array}{l}\text { gp41 } \\
\text { cluster I }\end{array}$ & $\mathrm{L}$ & $\mathrm{R}$ & $579-604[171,172]$ & n.a. & $\begin{array}{l}246-\mathrm{D}^{\mathrm{A}, \mathrm{E}}, 4 \mathrm{~B} 3^{\mathrm{A}} \\
98-43^{\mathrm{A}}, \mathrm{F} 240^{\mathrm{E}}\end{array}$ & n.a. \\
\hline $\begin{array}{l}\text { gp41 } \\
\text { cluster II }\end{array}$ & $\begin{array}{l}\mathrm{L} \\
\mathrm{D} \quad \mathrm{C}\end{array}$ & $\begin{array}{l}\mathrm{R} \\
\mathrm{R}\end{array}$ & $\begin{array}{l}\text { a) } 644-663[87] \\
\text { b) n.a. [87] }\end{array}$ & $\begin{array}{l}\text { Conformational masking (exposed } \\
\text { upon fusion) [88] }\end{array}$ & $\begin{array}{l}\text { a) } 120-16^{\mathrm{A}} \\
\text { b) } 98-6^{\mathrm{A}}, 126-50^{\mathrm{A}}\end{array}$ & n.a. \\
\hline gp41 MPER & $\mathrm{L} \quad \mathrm{C}$ & $\mathrm{R}$ & $\begin{array}{l}662-683[122,123, \\
173-175], \text { conserved } \\
\text { region with structural } \\
\text { plasticity }[176]\end{array}$ & $\begin{array}{l}\text { Transient exposure [177] } \\
\text { Steric hindrance [95] } \\
\text { Host mimicry [178] } \\
\text { Hydrophobicity [179] }\end{array}$ & $\begin{array}{l}4 \mathrm{E} 10^{\mathrm{bN}, \mathrm{A}}, 2 \mathrm{~F} 5^{\mathrm{bN}, \mathrm{A}} \\
\mathrm{Z} 13^{\mathrm{bN}}, 10 \mathrm{E} 8^{\mathrm{bN}} \\
\mathrm{m} 66.6^{\mathrm{bN}}\end{array}$ & $\begin{array}{l}\text { Binding to phospholipids [180], } \\
\text { possible contact through CDR } \\
\text { H3 Arg }(+)[181] \\
\text { Long CDR H3 [102] } \\
\text { Binding to auto-Ag }[178,179]\end{array}$ \\
\hline
\end{tabular}

$(-)$ = Negatively charged $(+)$ = positively charged; $\mathrm{Ag}=$ antigen; $\mathrm{Hu}-\mathrm{M}$ Abs = human monoclonal antibodies; $\mathrm{C}=$ continuous epitope; $\mathrm{D}=$ discontinuous epitope; $\mathrm{G}=$ glycan epitope; glyc = glycans; $\mathrm{L}=$ linear epitope; $\mathrm{N}=$ asparagine; $\mathrm{n} . \mathrm{a}$. = not available; $\mathrm{Q}=$ quaternary epitope (exclusive or preferential binding to trimer); $\mathrm{R}=$ amino acid residues; $\mathrm{V}_{\mathrm{H}}=$ variable heavy Ig domain.

${ }^{1}$ Domains as in figure 5 and amino acid residues numbered according to the HXB2 numbering scheme (www.hiv.lanl.gov).

${ }^{2} \mathrm{~A}=$ Antibody-dependent cellular cytotoxicity; $\mathrm{E}=$ enhancement of infection; $\mathrm{N}$ = neutralization; $\mathrm{bN}=$ broad neutralization; $\mathrm{wN}=$ weak neutralization; as referred in the www.hiv.lanl.gov immunology database.

${ }^{3}$ Suggested by $3 \mathrm{D}$ modeling. 
Table 5. gp120 peptides recognized by polyclonal antibodies of HIV-infected patients

\begin{tabular}{|c|c|c|c|c|c|c|}
\hline $\begin{array}{l}\text { Do- } \\
\text { main }\end{array}$ & $\begin{array}{l}\text { Peptide } \\
\text { position }^{1}\end{array}$ & $\begin{array}{l}\text { Analyzed } \\
\text { HIV-1 } \\
\text { clade }\end{array}$ & Peptide amino acid sequence & Ab type & $\begin{array}{l}\text { Cohort features } \\
\text { and prevalences of } \\
\text { recognition }\end{array}$ & Ref. \\
\hline \multirow[t]{2}{*}{$\mathrm{C} 1$} & $\underline{101-112}$ & $\mathrm{~B}$ & VEQMHEDIISLW & IgG & $\mathrm{RP}(\mathrm{n}=13)$ & [109] \\
\hline & $104-121$ & $\begin{array}{l}\text { A, B, } \\
\text { C, D }\end{array}$ & MHEDIISLWDQSLKPCVK2 & IgG & $C>A, B(n=169)$ & [54] \\
\hline \multirow[t]{2}{*}{$\mathrm{C} 1 / \mathrm{V} 1$} & $120-131$ & $\begin{array}{l}A, B \\
C, D\end{array}$ & VKLTPLCVTLNC & IgG & $\mathrm{C}>\mathrm{A}, \mathrm{B}(\mathrm{n}=169)$ & [54] \\
\hline & $123-157$ & $\mathrm{C}$ & TPLCVTLNCNTTSHNNSSPSPMTNC & IgG, $\operatorname{IgG}_{1}$ & $\begin{array}{l}\text { Af } 13 \%(n=15) \\
\text { Eu } 33 \%(n=15)\end{array}$ & [48] \\
\hline $\mathrm{V} 2$ & $173-197$ & $\mathrm{C}$ & NALFYRSDIVPLEKNSSEYILINCN & $\operatorname{IgG}>\operatorname{IgG}_{1}$ & $\begin{array}{l}\text { Af } 73 \%(n=15) \\
\text { Eu } 67 \%(n=15)\end{array}$ & [48] \\
\hline $\mathrm{C} 2$ & $193-217$ & $\mathrm{C}$ & LINCNTSTITQACPKVSFDPIPIHY & IgG, $\operatorname{IgG}_{1,3,4}$ & $\begin{array}{l}\text { Af } 20 \%(n=15) \\
\text { Eu } 40 \%(n=15)\end{array}$ & [48] \\
\hline \multirow[t]{4}{*}{ V3 } & $293-320$ & $\mathrm{C}$ & AIVCTRPNNNTRKSIRI - -GPGQVFYT & $\begin{array}{l}\operatorname{IgG} \operatorname{IgG}_{1-4} \text {, } \\
\text { IgA, IgM }\end{array}$ & $\begin{array}{l}\text { Af } 93 \%(n=15) \\
\text { Eu } 100 \%(n=15)\end{array}$ & [48] \\
\hline & $301-322$ & $\begin{array}{l}\text { A, B, } \\
\text { C, D }\end{array}$ & NNTRKSIRI - -GPGQTFYAIGD2 & IgG & n.a. high \% $(\mathrm{n}=169)$ & [54] \\
\hline & $303-312$ & $\mathrm{~B}$ & TRKSIRIQRGPG & IgG & $\begin{array}{l}\mathrm{RP}(\mathrm{n}=13)>\mathrm{SP} \\
(\mathrm{n}=13)\end{array}$ & [109] \\
\hline & $304-318$ & $\mathrm{~B}$ & RKSIRIQRGPGRAFV & $\operatorname{IgG}_{1}$ & $90 \%(n=10)$ & [51] \\
\hline \multirow[t]{2}{*}{$\mathrm{V} 3 / \mathrm{C} 3$} & $324-338$ & B & GNMRQAHCNISRAKW & $\operatorname{IgG}_{1}$ & $50 \%(\mathrm{n}=10)$ & {$[51]$} \\
\hline & $315-339$ & $\mathrm{C}$ & QVFYTNEIIGNIRQAHCNISRELWN & IgG & $\begin{array}{l}\text { Af } 100 \%(n=15) \\
\text { Eu } 100 \%(n=15)\end{array}$ & [27] \\
\hline \multirow[t]{2}{*}{$\mathrm{C} 3$} & $343-354$ & B & KQIASKLREQFG & $\operatorname{IgG}$ & $\begin{array}{l}\mathrm{SP}(\mathrm{n}=13)>\mathrm{RP} \\
(\mathrm{n}=13)\end{array}$ & [109] \\
\hline & $355-366$ & $\mathrm{~B}$ & NNKTIIFKQSSG & IgG & $\begin{array}{l}\mathrm{RP}(\mathrm{n}=13)>\mathrm{SP} \\
(\mathrm{n}=13)\end{array}$ & [109] \\
\hline \multirow[t]{2}{*}{ V4 } & $396-428$ & $\mathrm{C}$ & SNASDANNNTITLPCKIKQIINMWQ & $\operatorname{IgG}, \operatorname{IgG}_{1}$ & $\begin{array}{l}\text { Af } 20 \%(n=15) \\
\text { Eu } 20 \%(n=15) \\
\text { Af } \operatorname{IgG}_{1} 67 \%(n=15)\end{array}$ & {$[48]$} \\
\hline & $415-426$ & $\mathrm{~B}$ & TLPCRIKQFINM & IgG & $\mathrm{SP}(\mathrm{n}=13)$ & [109] \\
\hline \multirow[t]{7}{*}{ C5 } & $479-511$ & $\mathrm{C}$ & WRSELYKYKVVEIKPLGIAPTKAKRRVVEREKR & $\begin{array}{l}\operatorname{IgG}, \operatorname{IgG}_{1-4}, \\
\operatorname{IgA}\end{array}$ & $\begin{array}{l}\text { Af } 67 \%(n=15) \\
\text { Eu } 73 \%(n=15)\end{array}$ & [48] \\
\hline & $489-503$ & $\mathrm{~B}$ & KIEPLGVAPTKAKR & $\mathrm{IgG}_{1}$ & $90 \%(n=10)$ & [51] \\
\hline & $499-510$ & B & TKAKRRVVQREK & IgG & $\begin{array}{l}\mathrm{SP}(\mathrm{n}=13)>\mathrm{RP} \\
(\mathrm{n}=13)\end{array}$ & [109] \\
\hline & $503-514$ & $\mathrm{~B}$ & RRVVQREKRAVG & IgG & $\begin{array}{l}\mathrm{SP}(\mathrm{n}=13)>\mathrm{RP} \\
(\mathrm{n}=13) \\
\text { RRVVQREKRAVG }< \\
\text { TKAKRRVVQREK }\end{array}$ & [109] \\
\hline & $497-511$ & $\mathrm{~B}$ & APTKAKRRVVNREKR & Ig-IC & $45 \%(n=42)$ & [110] \\
\hline & $496-521$ & B & VAPTKAKRRVVQREKRAVGIGALFLG & Total Ig & $\begin{array}{l}\text { Af 53\% }(n=159) \\
\text { USA 39\% }(n=103)\end{array}$ & [111] \\
\hline & $504-516$ & $\begin{array}{l}\text { A, B, } \\
\text { C, D }\end{array}$ & RVVEREKRAVGIG2 & IgG & n.a. high $\%(\mathrm{n}=169)$ & [54] \\
\hline
\end{tabular}

A = HIV-1 clade A; B = HIV-1 clade B; C = HIV-1 clade C; D = HIV-1 clade D; Ab = antibody; Af = African; Eu = European; Ig = immunoglobulin Ig-IC = immunoglobulin immune complex; $\mathrm{n}=$ number of subjects; $\mathrm{n} . \mathrm{a} .=$ not available; $\mathrm{RP}=$ rapid progressors; $\mathrm{SP}=$ slow progressors; $>=$ higher prevalence of recognition than comparison group; $<=$ lower prevalence of recognition than comparison group.

${ }^{1}$ HXB2 numbering; www.hiv.lanl.gov. ${ }^{2}$ Reactivity was tested towards peptides from different strains, but only the clade $\mathrm{C}$ sequence is shown here.

assays with Env-pseudotyped viruses were useful for the definition of quaternary epitopes $[15,83,84]$.

Table 4 summarizes Env epitopes, their type and molecular features (e.g. gp120 and gp41 domains involved) and examples of human monoclonal antibodies targeting these epitopes. Some Env-specific antibodies recognize protein regions involved in receptor and coreceptor binding (e.g. CD4-binding site, CD4-induced epitope and V3 loop) $[6,10,40,85,86]$. Some bind regions that are exposed after conformational changes necessary for fusion of the viral membrane with the target-cell membrane (e.g. gp41 cluster II) [87, 88]. Other Env-specific antibodies 
bind conformational epitopes constituted by Env domains and attached glycans (e.g. V1V2, V3 crown and glycans) or by glycans alone (e.g. gp120 glycan-only) [8, $39,81,82,89,90]$. When modeled on the cryo-electron tomography pictures of the Env trimer, the epitopes represent mainly independent surface patches [91-93].

Great attention has been dedicated to the elucidation of the structural determinants that permit the virus to escape antibody binding (i.e. features of the Env protein) and the ones that permit the antibody to make contacts to a highly glycosylated protein able to adopt several conformations (i.e. unique features of the antibody). Immune escape can be mediated for example by steric hindrance, masked by variable loops, mutation and glycosylation shielding amino acid residues [40, 55, 94-100]. On the other hand, several unique features have been shown to be essential for antibody neutralization. Some of these regard the antibody's complementarity-determining regions (CDRs), which are usually engaged in antigen contact. For example, long CDR H3 can mediate recognition of the CD4-binding site or of the coreceptor-binding site and penetration of the glycan shield or contact to the hydrophobic MPER (membrane proximal external region) epitope $[9,80-82,101,102]$. Short CDR L3 loops can mediate CD4 mimicry and CDR H2 can also be involved in the penetration of the glycan shield [81, 103]. Unique mechanisms, such as heavy chain-only contact or domain-swapped Fabs (antigen-binding fragments), have been shown to characterize bNAb that bind to the gp120 inner domain and to the gp120 glycan-only epitope, respectively $[8,90]$. Extensive somatic mutations seem to play a major role in the acquirement of these unique features and of high antigen affinity [104]. Details of the escape and binding mechanisms have been reviewed elsewhere in relation to the structure of the epitopes [92].

However, monoclonal antibodies only represent single antibodies occurring in a polyclonal antibody response and, therefore, do not reflect the polyclonal antibody response in HIV-infected patients. An elegant study by Kwong and colleagues [105] showed that for sera with broadly neutralizing activity the Env specificities could be mapped using clusters of HIV-1 isolate-neutralization patterns identified for human monoclonal antibodies, but bNAb are very rare during natural HIV infection (e.g. $1.7-3.7 \%$ [106], 4-11\% [107], 6\% [108]).

\section{gp120 and gp41 Linear Epitopes Recognized by the}

Polyclonal Antibodies of Patients

Despite the high glycosylation rate of the Env, HIVinfected patients mount strong polyclonal antibody re-

HIV-Specific Antibodies - Isotypes and Specificity sponses against linear epitopes constituted by Env peptides. Most of the information regarding linear epitopes derives from early reports using HIV subtype B synthetic peptides to define the specificity of IgG responses in HIV infected patients [51, 109-116]. Recently, Gottardo et al. [54] used a panel of short peptides from different clades to map the binding sites of IgG antibodies. We obtained similar results with a peptide array of 25 -mer peptides from HIV-1 clade C $[27,48]$.

Tables 5 and 6 summarize the results obtained from gp120 and gp41 peptide-based mapping studies for which information regarding peptide amino acid sequences, cohorts and antibody prevalence were available $[27,48,51$, 54, 109-116]. The amino acid sequences common to peptides recognized by specific antibodies are listed in tables 5 and 6, and are displayed in relation to gp120 and gp41 domains in figure 5 . The gp120 peptides that were most frequently recognized shared the following sequences: 304-RKSIRIxxGPG-314, 325-GNxRQAHCNISRxxW-338 and 489-(E/K)I(K/E)PLGxAPTKAKR-503. They were located in the V3 loop, a region downstream of V3, and in the $\mathrm{C} 5$ region, respectively. Importantly, these major epitopes were located outside the gp120 CD4-binding site. For gp41, frequently recognized sequences were: 562-GIKQLQARV-580, 583-(V/I)ERYLKDQQL-592 and 593-LG(I/L)WGCSGKLIC-604. These sequences cluster in the region 562-604, which starts within the first heptad repeat involved in the membrane fusion process [117119]. It is interesting that HIV-specific antibodies also target the gp $41 \mathrm{C}$-terminal region [i.e. 843-IPRRIRQG(F/ L)E-852], which is part of the gp41 cytoplasmic domain $[120,121]$.

Figure 5 also shows the position of linear epitopes targeted by human monoclonal antibodies. Linear epitopes recognized by monoclonal antibodies often overlap with the major targets of the polyclonal responses. However, a difference is found in the gp41 MPER: polyclonal peptide-specific responses cluster to the $\mathrm{N}$-terminal part of the domain (which is also recognized by human monoclonal antibody 2F5), but they do not recognize the more membrane-proximal region bound by neutralizing monoclonal antibodies Z13 and 4E10 (fig. 5; table 6) [48, $54,109,122,123]$.

\section{IgG Subclass Distribution of Env-Specific Antibodies during HIV Infection}

Relatively few studies have investigated the IgG subclass and isotype distribution of antibody responses in HIV-infected patients. Env-specific antibodies were found to be dominated by strong $\operatorname{IgG}_{1}$ responses and in 


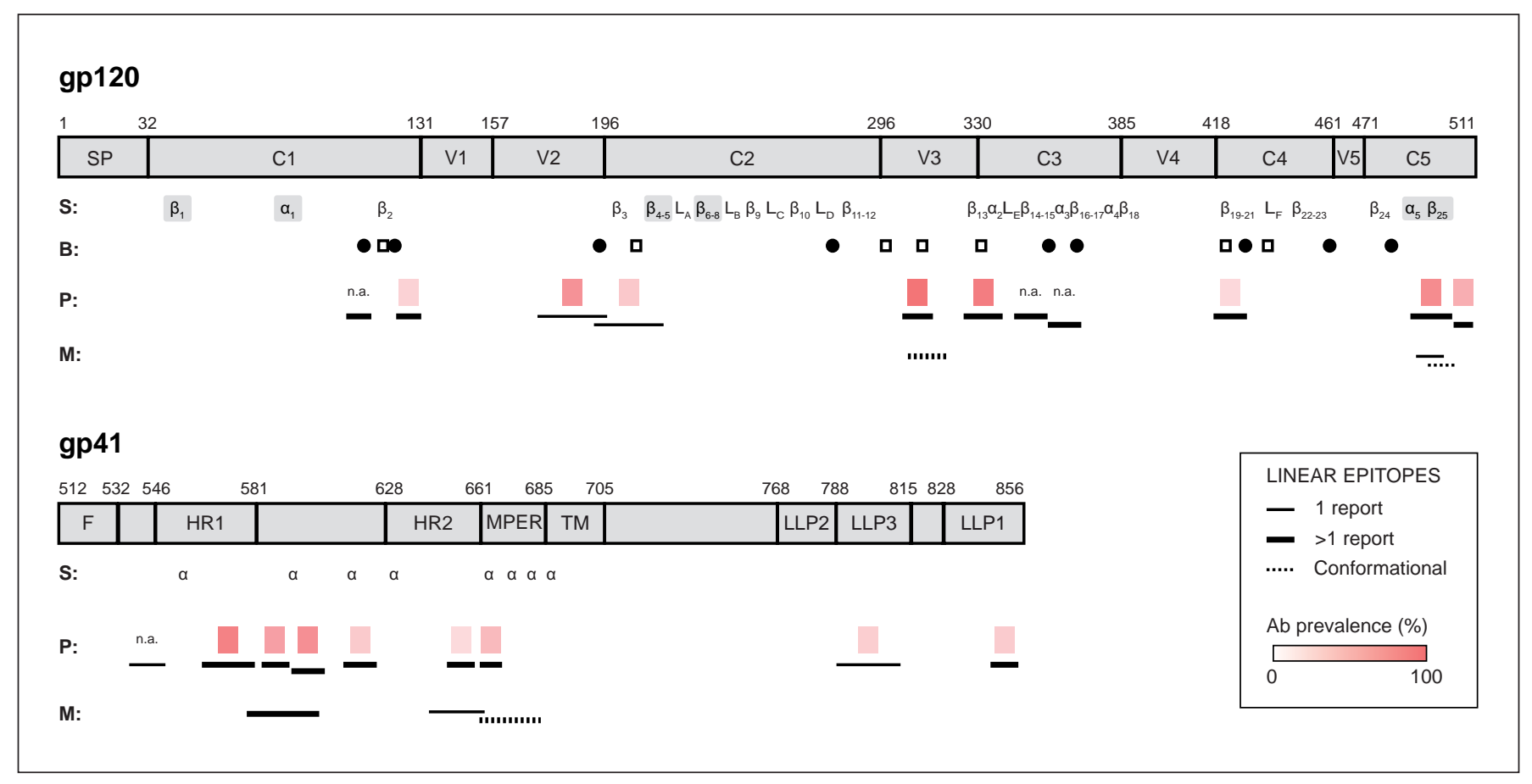

Fig. 5. Schemes of gp120 and gp41 domains, secondary structures and linear epitopes recognized by polyclonal and monoclonal IgG antibodies of HIV-infected patients. The position of domains and secondary structural elements (S) are indicated for gp120 and gp41 from HIV-1 reference isolate HXB2 (www.unirpot.org; Acc. No. P04578), numbered according to the HXB2 numbering scheme (www.hiv.lanl.gov). Alpha-helixes ( $\alpha$ ), beta-sheet elements $(\beta)$ and loops (L) are labelled and numbered [6]. The position of HR and LLP domains were defined as in Postler and Desrosiers [121] and Chan et al. [161], respectively. Secondary structural elements composing the 'gp120 inner domain' are boxed [6]. The approximate positions of CD4 and CCR5 coreceptor-binding sites (B) are indicated (filled circles and empty boxes, respectively) $[9,10,162]$. Lin-

some studies to be accompanied by $\operatorname{IgA}$ and $\operatorname{IgM}[48$, $124,125]$. Env-specific $\operatorname{IgG}_{2}, \operatorname{IgG}_{3}$ and $\operatorname{IgG}_{4}$ responses have been detected less frequently $[48,113,124]$. Differences among Env-specific IgG subclass prevalence have been reported regarding the specificity of the response and the levels over time. For example, it has been reported that during the first 6 months postinfection gp120-specific $\operatorname{IgG}_{1}$ remains constant while gp120-specific $\mathrm{IgG}_{3}$ peaks after 1 month and then decline [126]. Analyzing HIV-1 clade C-specific responses in African and European $\mathrm{HIV}$-infected subjects, we recently showed that the IgG subclass distribution for gp120 recombinant protein and gp120-derived peptides was: $\mathrm{IgG}_{1}>\mathrm{IgG}_{2}, \mathrm{IgG}_{4}>\mathrm{IgG}_{3}$. The IgG antibodies towards gp41 peptides were predominantly $\operatorname{IgG}_{1}$ [48]. A similar ear epitopes recognized by polyclonal (P) and monoclonal (M) antibodies from HIV-infected patients are indicated. Mean prevalences of positive peptide-specific reactivity (color-coded) are shown for polyclonal responses of HIV-infected patients reported in tables 5 and 6 . Peptides identified in at least 2 independent studies are indicated by bold lines, peptides reported in single studies are marked by simple lines, and peptides that are part of conformational epitopes are identified by a dashed line. SP $=$ Signal peptide; $\mathrm{C} 1-5=$ conserved regions; $\mathrm{V} 1-5=$ variable regions; $\mathrm{F}=$ fusion peptide; HR1-2 = heptad repeat; $\mathrm{MPER}=$ membrane proximal external region; $\mathrm{TM}=$ transmembrane domain; LLP1-3 = lentiviral lytic peptide; n.a. = not analyzed.

predominance of $\mathrm{IgG}_{1}$ responses to gp41 peptides was observed, whereas a predominant $\operatorname{IgG}_{1}$ and $\operatorname{IgG}_{3}$ gp120specific response was found in early epitope mapping studies with samples of a small cohort of HIV-infected homosexual men [51].

Studying the concurrent presence of IgG subclasses in individual samples of infected subjects, we found that $\mathrm{HIV}$-specific responses other than $\mathrm{IgG}_{1}$ occurred most frequently in the following patterns: $\mathrm{IgG}_{2}+\mathrm{IgG}_{4}>\mathrm{IgG}_{4}>$ $\mathrm{IgG}_{2}+\mathrm{IgG}_{3}+\mathrm{IgG}_{4}$ [48; Gallerano, unpubl. data]. A previous study found that gp140-specific $\mathrm{IgG}_{2}$ and $\mathrm{IgG}_{3}$ responses did not occur simultaneously in HIV-infected individuals [124].

The protective potential of Env-specific antibody responses of the different IgG subclasses still has to be elu- 
Table 6. gp41 peptides recognized by polyclonal antibodies of HIV-infected patients

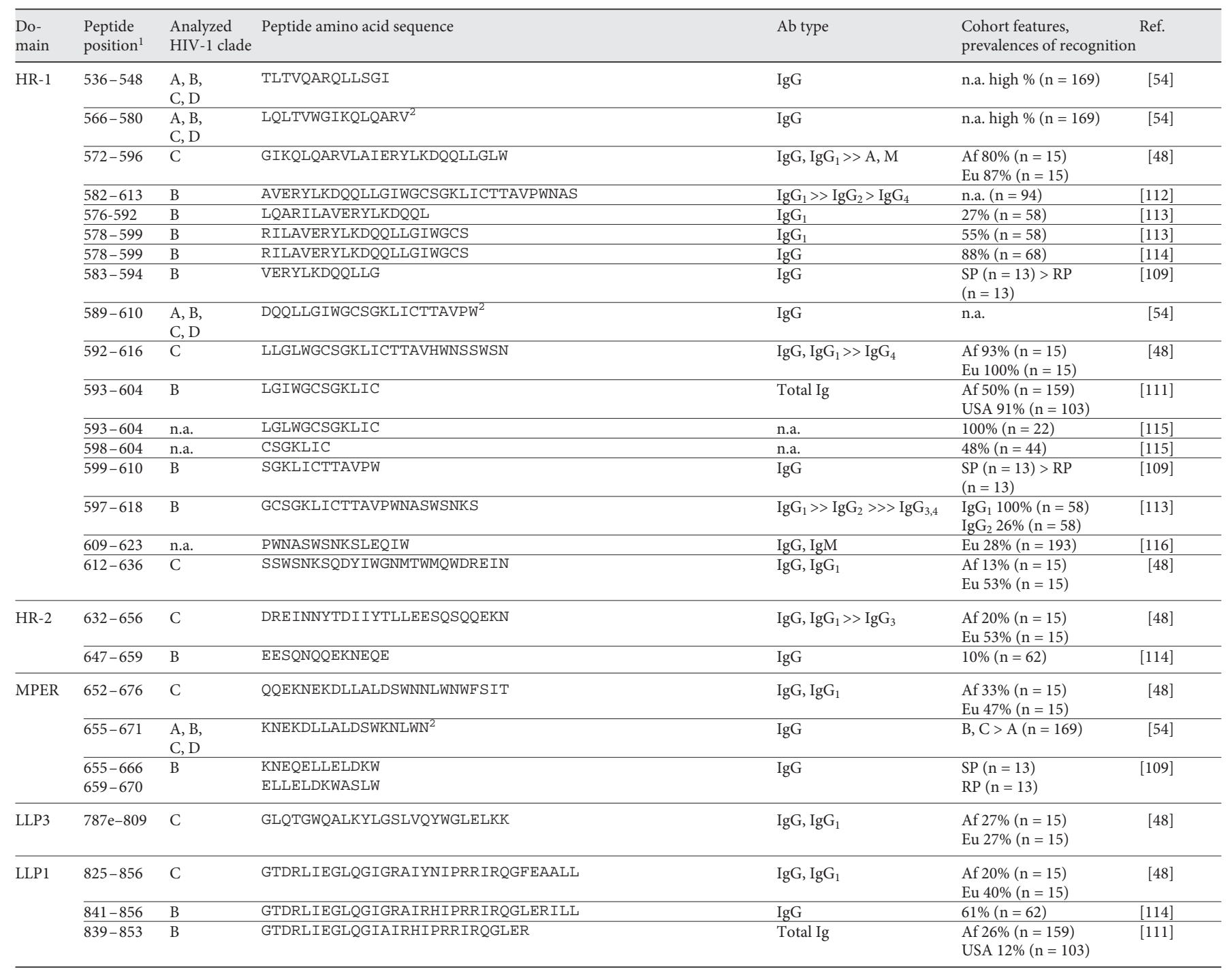

A = HIV-1 clade A; B = HIV-1 clade B; C = HIV-1 clade C; Ab = antibody; Af = African; Eu = European; Ig = immunoglobulin; $\mathrm{n}=$ number of subjects; $\mathrm{n} . \mathrm{a} .=$ not available; RP = rapid progressors; $\mathrm{SP}=$ slow progressors; > = higher prevalence of $\mathrm{Ab}$ recognition than comparison group; $<=$ lower prevalence of $\mathrm{Ab}$ recognition than comparison group.

${ }^{1} \mathrm{HXB} 2$ numbering scheme with numbers indicating amino acid sequence position and letters indicating inserted amino acids compared to the HXB2 sequence, www.hiv.lanl.gov.

${ }^{2}$ Reactivity was tested towards peptides from different strains, but only the clade C sequence is shown here.

cidated. Higher gp120-specific $\operatorname{IgG}_{1}$ titers and gp120-specific $\mathrm{IgG}_{3}$ prevalence has been observed in HIV controllers compared to progressors [45]. Interestingly, antibody responses directed to gp41 may be correlated both with progression or control, depending on the subclass and epitope specificity. For example, IgG 1 levels directed to linear epitopes in the gp41 immunodominant region 578-622 are higher during chronic infection and progression [127]. On the contrary, there is evidence that gp41-specific IgG $\mathrm{Ig}_{2}$ may be associated with nonprogression [128-130]. In fact, it is quite possible that patients with reactivities in $\mathrm{IgG}$ subclasses which exhibit less complement activation and/ or ADCC experience less killing of their immune cells and therefore have a better prognosis [131]. Analyses of largesample cohorts for which clinical information is available would be very useful to elucidate if individual profiles of antibody isotype/subclass recognition of Env epitopes are associated with certain courses of disease, symptoms or response to medication. 
Table 7. Polyclonal antibodies specific for non-Env proteins

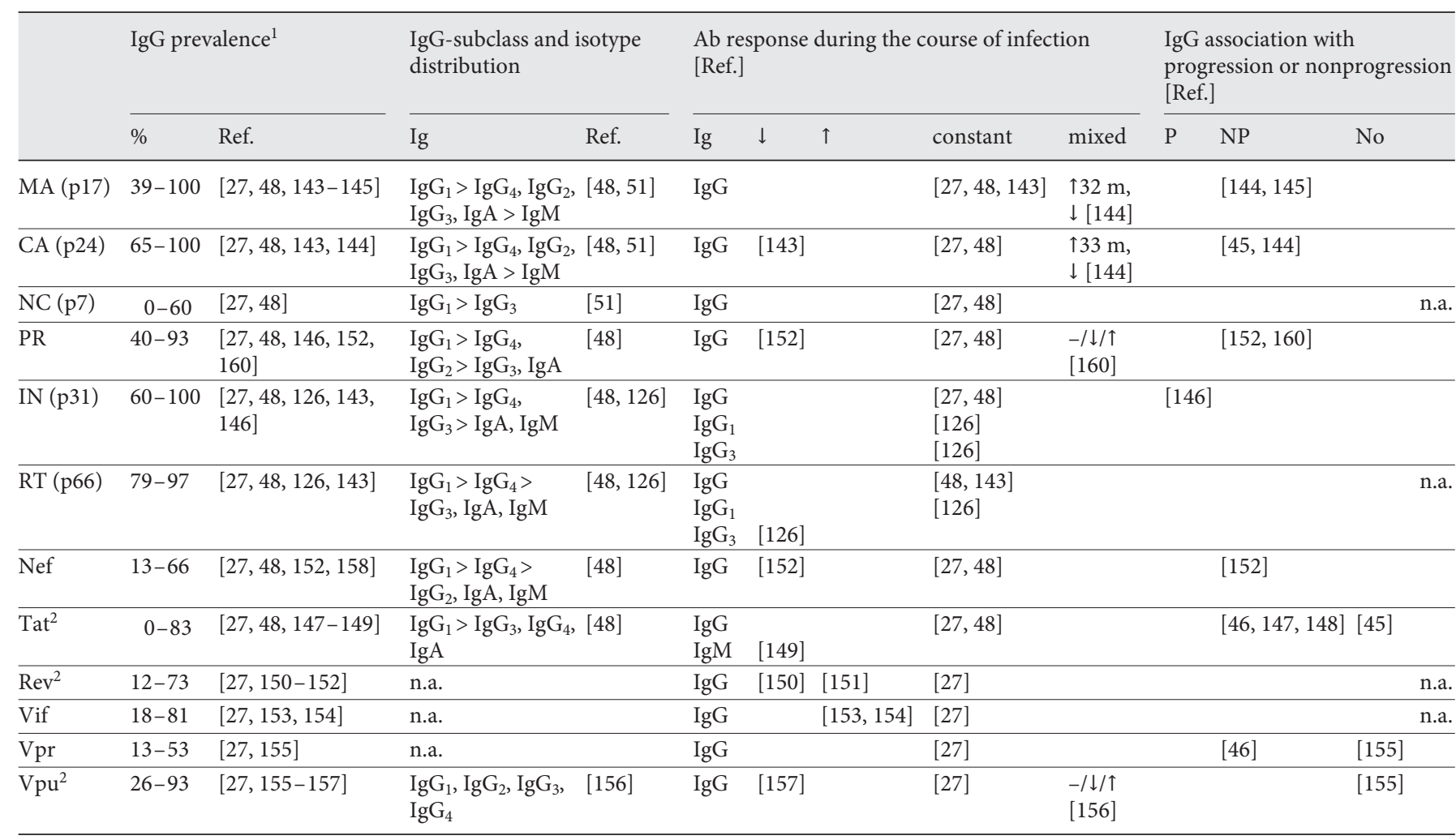

$\downarrow=$ Decrease of Ab levels or prevalence; $\uparrow=$ increase of Ab levels or prevalence; $-/ \downarrow / \uparrow=$ constant, decreasing or increasing Ab levels or prevalence observed in the same study; $\mathrm{Ab}=$ antibody; $\mathrm{m}=$ months; $\mathrm{n} . \mathrm{a}$. = not available; $\mathrm{P}=$ progression (defined as progression to $\mathrm{AIDS}=$ low $\mathrm{CD} 4$ or high viral load); $\mathrm{NP}=$ nonprogression; $\mathrm{No}=$ no association.

${ }^{1}$ IgG prevalence range observed in cohorts of HIV-infected individuals. ${ }^{2}$ Not expressed in the virion, but only in the infected cell.

\section{Antibody Responses Directed towards Structural, Functional and Accessory Proteins}

Besides antibodies recognizing Env surface antigens, HIV-infected individuals also develop antibodies targeting structural (p17, p24, p7), functional (p66, PR, p31) and accessory proteins (Nef, Tat, Rev, Vif, Vpr, Vpu). These proteins are not present on the surface of the virion - certain of them are not even found within the virion, but instead only in infected cells (e.g. Tat, Rev, Vpu) - but they can be exposed to the immune system upon the destruction of infected cells [20]. Additionally, some proteins are found on the membrane of infected cells (i.e. p24, p17, Nef, Tat and Vpu) [132-136] and some are even secreted from infected cells and can be found in serum and cerebrospinal fluid (i.e. p24, p7, Nef, Tat and Vpr) [135, 137-140]. The relevance of HIV reservoirs in eliciting immune responses still has to be clarified; however, persistence of viral antigens has been shown to cause sub- sequent waves of immune stimulation during chronic infections [141, 142]. Table 7 summarizes the prevalence and isotype/subclass distribution of antibody responses against non-Env proteins. The most frequently recognized targets are structural p17, p24 and pol-derived p31 and p66 (table 7) [27, 48, 126, 143-146]. In fact, diagnostic tests, such as confirmatory Western blot, are based on the additional detection of p17, p24 and p31-specific IgG (e.g. InnoLIA, Innogenetics, Ghent, Belgium). Interestingly, specific antibodies are also elicited against accessory proteins with a variable IgG prevalence (table 7) [27, 48, 147-158].

The isotype/subclass distribution of antibodies recognizing non-Env proteins is less well characterized (table 7). However, we recently analyzed reactivity profiles using a panel of HIV-1 clade $\mathrm{C}$ recombinant proteins [48]. Strong $\operatorname{IgG}_{1}$ responses were accompanied mainly by $\mathrm{IgG}_{4}$ responses. Additionally, $\mathrm{IgG}_{2}$ responses were frequently detected against p24 and PR, and $\operatorname{IgG}_{3}$ responses 
against p24 and p31 [48]. The mechanisms that lie behind the differential production of antibody subclasses for the individual proteins still have to be understood. Interestingly, a new mechanism of HIV evasion from antibody responses has recently been described that affects only single antibody types [159]. $\operatorname{IgG}_{2}$ and IgA class switch was attenuated by intercellular shuttling of the accessory protein Nef from infected macrophages to B cells. In patients, the mechanism affected only single specificities. In fact, it has been reported that individuals naturally infected with virus variants lacking Nef had higher gp120-specific $\operatorname{IgA}_{2}$, p24-specific $\operatorname{IgG}_{2}, \operatorname{IgA}_{1}$ and $\operatorname{Ig} A_{2}$, and Tat-specific $\operatorname{IgG}_{2}$ and $\mathrm{IgA}_{2}$ responses [159].

Studies using follow-up serum samples of HIV-infected patients provided some insights into the course of antibody responses over time (table 7). Interestingly, proteinand peptide-specific antibody responses showed mainly constant patterns during the course of infection [27, 48, $126,143]$. However, during acute infection antibodies targeting p17 and p 24 increased in the first 32 and 33 months, respectively, and then decreased during progression [144]. An important question in this regard is whether the presence/titer of antibodies specific for individual proteins is predictive of a certain clinical course of the disease. For example, it has been shown that p17, p24 and PR-specific antibodies were associated with nonprogression or a stable clinical status $[45,144,145,152,160]$. On the other hand, p31-specific antibodies were found to be associated with a worse prognosis, and results obtained for Tat- and Vprspecific responses were controversial (table 7 ) $[45,46,146-$ $148,155]$. The use of antibody reactivity patterns as prognostic markers has not yet been established for the clinical practice. Analyzed cohorts differed in many aspects, such as the infection route and definition of clinical staging, as well as in the sensitivity of immunoassays and antigens used. It would be very interesting to investigate whether a set of antibody reactivities with prognostic value could be identified analyzing antibody responses directed towards Env as well as non-Env proteins in parallel, and including the dissection of isotypes and subclasses.

\section{Concluding Remarks}

Several neutralizing human monoclonal HIV-specific antibodies have been identified and their characterization has contributed to the elucidation of the structural determinants of antibody-antigen interactions. However, such antibodies occur only in a minority of HIV-infected patients and represent a small fraction of the patients' polyclonal HIV-specific antibody responses. Studies analyzing the specificities of the polyclonal antibody responses in HIV-infected patients have shown that the antibodies which develop during natural infection are misdirected towards epitopes that are outside of the gp120 CD4-binding site, and against proteins inside the virion or on virusinfected cells, and therefore cannot block the binding of the virus to CD4 cells. Since a considerable proportion of the Env-specific antibodies is directed against certain peptides, it may be possible to use such peptides for diagnostic tests to find out if they can eventually be used to discriminate infection with certain strains. Furthermore, engineering HIV vaccines to redirect the antibody response towards the CD4-binding sites in order to obtain effective therapeutic and prophylactic vaccines for HIV must be considered.

\section{Acknowledgements}

This work was supported by a research grant from Biomay AG, Vienna, Austria.

\section{References}

-1 Gallo RC, Sarin PS, Gelmann EP, Robert-Guroff M, Richardson E, Kalyanaraman VS, Mann D, Sidhu GD, Stahl RE, Zolla-Pazner S, Leibowitch J, Popovic M: Isolation of human T-cell leukemia virus in acquired immune deficiency syndrome (AIDS). Science 1983;220:865-867.

-2 Barre-Sinoussi F, Chermann JC, Rey F, Nugeyre MT, Chamaret S, Gruest J, Dauguet C, Axler-Blin C, Vezinet-Brun F, Rouzioux C, Rozenbaum W, Montagnier L: Isolation of a T-lymphotropic retrovirus from a patient at risk for acquired immune deficiency syndrome (AIDS). Science 1983;220:868-871

HIV-Specific Antibodies - Isotypes and Specificity
13 Case K: Nomenclature: human immunodeficiency virus. Ann Intern Med 1986;105:133.

-4 Pinter A, Honnen WJ, Tilley SA, Bona C, Zaghouani H, Gorny MK, Zolla-Pazner S: Oligomeric structure of gp41, the transmembrane protein of human immunodeficiency virus type 1. J Virol 1989;63:2674-2679.

5 Koch M, Pancera M, Kwong PD, Kolchinsky P, Grundner C, Wang L, Hendrickson WA, Sodroski J, Wyatt R: Structure-based, targeted deglycosylation of HIV-1 gp120 and effects on neutralization sensitivity and antibody recognition. Virology 2003;313:387-400.
6 Kwong PD, Wyatt R, Robinson J, Sweet RW, Sodroski J, Hendrickson WA: Structure of an HIV gp120 envelope glycoprotein in complex with the CD4 receptor and a neutralizing human antibody. Nature 1998;393:648-659.

7 Wyatt R, Kwong PD, Desjardins E, Sweet RW, Robinson J, Hendrickson WA, Sodroski JG: The antigenic structure of the HIV gp120 envelope glycoprotein. Nature 1998;393:705-711. 
8 Calarese DA, Scanlan CN, Zwick MB, Deechongkit S, Mimura Y, Kunert R, Zhu P, Wormald MR, Stanfield RL, Roux KH, Kelly JW, Rudd PM, Dwek RA, Katinger H, Burton DR, Wilson IA: Antibody domain exchange is an immunological solution to carbohydrate cluster recognition. Science 2003;300:20652071.

\9 Huang CC, Lam SN, Acharya P, Tang M, Xiang SH, Hussan SS, Stanfield RL, Robinson J, Sodroski J, Wilson IA, Wyatt R, Bewley CA, Kwong PD: Structures of the CCR $5 \mathrm{~N}$ terminus and of a tyrosine-sulfated antibody with HIV-1 gp120 and CD4. Science 2007;317:1930-1934.

10 Zhou T, Xu L, Dey B, Hessell AJ, van Ryk D, Xiang SH, Yang X, Zhang MY, Zwick MB, Arthos J, Burton DR, Dimitrov DS, Sodroski J, Wyatt R, Nabel GJ, Kwong PD: Structural definition of a conserved neutralization epitope on HIV-1 gp120. Nature 2007;445:732-737.

-11 Zhu P, Liu J, Bess J Jr, Chertova E, Lifson JD, Grise H, Ofek GA, Taylor KA, Roux KH: Distribution and three-dimensional structure of AIDS virus envelope spikes. Nature 2006;441: 847-852.

12 Zanetti G, Briggs JA, Grunewald K, Sattentau QJ, Fuller SD: Cryo-electron tomographic structure of an immunodeficiency virus envelope complex in situ. PLoS Pathog 2006;2:e83.

13 Scheid JF, Mouquet H, Feldhahn N, Walker BD, Pereyra F, Cutrell E, Seaman MS, Mascola JR, Wyatt RT, Wardemann H, Nussenzweig MC: A method for identification of HIV gp140 binding memory B cells in human blood. J Immunol Methods 2009;343:65-67.

14 Scheid JF, Mouquet H, Feldhahn N, Seaman MS, Velinzon K, Pietzsch J, Ott RG, Anthony RM, Zebroski H, Hurley A, Phogat A, Chakrabarti B, Li Y, Connors M, Pereyra F, Walker $\mathrm{BD}$, Wardemann H, Ho D, Wyatt RT, Mascola JR, Ravetch JV, Nussenzweig MC: Broad diversity of neutralizing antibodies isolated from memory B cells in HIV-infected individuals. Nature 2009;458:636-640.

15 Walker LM, Phogat SK, Chan-Hui PY, Wagner D, Phung P, Goss JL, Wrin T, Simek MD, Fling S, Mitcham JL, Lehrman JK, Priddy FH, Olsen OA, Frey SM, Hammond PW, Kaminsky S, Zamb T, Moyle M, Koff WC, Poignard P, Burton DR: Broad and potent neutralizing antibodies from an African donor reveal a new HIV-1 vaccine target. Science 2009;326:285-289.

-16 Klein F, Halper-Stromberg A, Horwitz JA, Gruell H, Scheid JF, Bournazos S, Mouquet H, Spatz LA, Diskin R, Abadir A, Zang T, Dorner M, Billerbeck E, Labitt RN, Gaebler C, Marcovecchio $P M$, Incesu RB, Eisenreich TR, Bieniasz PD, Seaman MS, Bjorkman PJ, Ravetch JV, Ploss A, Nussenzweig MC: HIV therapy by a combination of broadly neutralizing antibodies in humanized mice. Nature 2012;492:118122.

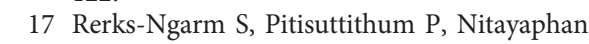
S, Kaewkungwal J, Chiu J, Paris R, Premsri N, Namwat C, de Souza M, Adams E, Benenson M, Gurunathan S, Tartaglia J, McNeil JG, Francis DP, Stablein D, Birx DL, Chunsuttiwat $S$, Khamboonruang C, Thongcharoen P, Robb ML, Michael NL, Kunasol P, Kim JH: Vaccina- tion with ALVAC and AIDSVAX to prevent HIV-1 infection in Thailand. N Engl J Med 2009;361:2209-2220.

18 Haynes BF, Gilbert PB, McElrath MJ, ZollaPazner S, Tomaras GD, Alam SM, Evans DT, Montefiori DC, Karnasuta C, Sutthent R, Liao HX, DeVico AL, Lewis GK, Williams C, Pinter A, Fong Y, Janes H, DeCamp A, Huang Y, Rao M, Billings E, Karasavvas N, Robb ML, Ngauy V, de Souza MS, Paris R, Ferrari G, Bailer RT, Soderberg KA, Andrews C, Berman PW, Frahm N, de Rosa SC, Alpert MD, Yates NL, Shen X, Koup RA, Pitisuttithum P, Kaewkungwal J, Nitayaphan S, Rerks-Ngarm S, Michael NL, Kim JH: Immune-correlates analysis of an HIV-1 vaccine efficacy trial. N Engl J Med 2012;366:1275-1286.

19 Chung AW, Ghebremichael M, Robinson H, Brown E, Choi I, Lane S, Dugast AS, Schoen MK, Rolland M, Suscovich TJ, Mahan AE, Liao L, Streeck H, Andrews C, Rerks-Ngarm S, Nitayaphan S, de Souza MS, Kaewkungwal J, Pitisuttithum P, Francis D, Michael NL, Kim JH, Bailey-Kellogg C, Ackerman ME, Alter G: Polyfunctional Fc-effector profiles mediated by IgG subclass selection distinguish RV144 and VAX003 vaccines. Sci Transl Med 2014;6: 228ra238.

20 Swanson CM, Malim MH: SnapShot: HIV-1 proteins. Cell 2008;133:742, 742 e741.

21 Klein KC, Reed JC, Lingappa JR: Intracellular destinies: degradation, targeting, assembly, and endocytosis of HIV Gag. AIDS Rev 2007; 9:150-161.

22 Lai JI, Licht AF, Dugast AS, Suscovich T, Choi I, Bailey-Kellogg C, Alter G, Ackerman ME: Divergent antibody subclass and specificity profiles but not protective HLA-B alleles are associated with variable antibody effector function among HIV-1 controllers. J Virol 2014;88:2799-2809.

23 Robinson WH, DiGennaro C, Hueber W, Haab BB, Kamachi M, Dean EJ, Fournel S, Fong D, Genovese MC, de Vegvar HE, Skriner K, Hirschberg DL, Morris RI, Muller S, Pruijn GJ, van Venrooij WJ, Smolen JS, Brown PO, Steinman L, Utz PJ: Autoantigen microarrays for multiplex characterization of autoantibody responses. Nat Med 2002;8:295-301.

24 Gaseitsiwe S, Valentini D, Mahdavifar S, Magalhaes I, Hoft DF, Zerweck J, Schutkowski M, Andersson J, Reilly M, Maeurer MJ: Pattern recognition in pulmonary tuberculosis defined by high content peptide microarray chip analysis representing 61 proteins from $M$. tuberculosis. PLoS One 2008;3:e3840.

25 Panzner P, Vachová M, Vítovcová P, Brodská $\mathrm{P}$, Vlas T: A comprehensive analysis of middleEuropean molecular sensitization profiles to pollen allergens. Int Arch Allergy Immunol 2014;164:74-82.

26 Lupinek C, Wollmann E, Baar A, Banerjee S, Breiteneder H, Broecker BM, Bublin M, Curin M, Flicker S, Garmatiuk T, Hochwallner H, Mittermann I, Pahr S, Resch Y, Roux KH, Srinivasan B, Stentzel S, Vrtala S, Willison LN, Wickman M, Lodrup-Carlsen KC, Anto JM, Bousquet J, Bachert C, Ebner D, Schlederer T, Harwanegg C, Valenta R: Advances in aller- gen-microarray technology for diagnosis and monitoring of allergy: the MeDALL allergenchip. Methods 2014;66:106-119.

27 Gallerano D, Wollmann E, Lupinek C, Schlederer T, Ebner D, Harwanegg C, Niespodziana K, Schmetterer K, Pickl W, PuchhammerStockl E, Sibanda E, Valenta R: HIV microarray for the mapping and characterization of HIV-specific antibody responses. Lab Chip 2015;15:1574-1589.

28 Hildgartner A, Wilflingseder D, Gassner C, Dierich MP, Stoiber H, Banki Z: Induction of complement-mediated lysis of HIV-1 by a combination of HIV-specific and HLA allotype-specific antibodies. Immunol Lett 2009; 126:85-90.

29 Huber M, von Wyl V, Ammann CG, Kuster H, Stiegler G, Katinger H, Weber R, Fischer M, Stoiber H, Gunthard HF, Trkola A: Potent human immunodeficiency virus-neutralizing and complement lysis activities of antibodies are not obligatorily linked. J Virol 2008;82: 3834-3842.

30 Lan J, Yang K, Byrd D, Hu N, Amet T, Shepherd N, Desai M, Gao J, Gupta S, Sun Y, Yu Q: Provirus activation plus CD59 blockage triggers antibody-dependent complement-mediated lysis of latently HIV-1-infected cells. J Immunol 2014;193:3577-3589.

- 31 Pollara J, Hart L, Brewer F, Pickeral J, Packard BZ, Hoxie JA, Komoriya A, Ochsenbauer C, Kappes JC, Roederer M, Huang Y, Weinhold KJ, Tomaras GD, Haynes BF, Montefiori DC, Ferrari G: High-throughput quantitative analysis of HIV-1 and SIV-specific ADCC-mediating antibody responses. Cytometry A 2011;79: 603-612.

32 Gomez-Roman VR, Florese RH, Patterson LJ, Peng B, Venzon D, Aldrich K, Robert-Guroff M: A simplified method for the rapid fluorometric assessment of antibody-dependent cellmediated cytotoxicity. J Immunol Methods 2006;308:53-67.

33 Chung AW, Rollman E, Center RJ, Kent SJ, Stratov I: Rapid degranulation of NK cells following activation by HIV-specific antibodies. J Immunol 2009;182:1202-1210.

34 Ackerman ME, Moldt B, Wyatt RT, Dugast AS, McAndrew E, Tsoukas S, Jost S, Berger CT, Sciaranghella G, Liu Q, Irvine DJ, Burton DR, Alter G: A robust, high-throughput assay to determine the phagocytic activity of clinical antibody samples. J Immunol Methods 2011;366:8-19.

35 Li M, Gao F, Mascola JR, Stamatatos L, Polonis VR, Koutsoukos M, Voss G, Goepfert P, Gilbert P, Greene KM, Bilska M, Kothe DL, Salazar-Gonzalez JF, Wei X, Decker JM, Hahn BH, Montefiori DC: Human immunodeficiency virus type 1 env clones from acute and early subtype B infections for standardized assessments of vaccine-elicited neutralizing antibodies. J Virol 2005;79:10108-10125.

- 36 Burton DR, Pyati J, Koduri R, Sharp SJ, Thornton GB, Parren PW, Sawyer LS, Hendry RM, Dunlop N, Nara PL, et al: Efficient neutralization of primary isolates of HIV-1 by a recombinant human monoclonal antibody. Science 1994;266:1024-1027. 
- 37 Muster T, Guinea R, Trkola A, Purtscher M, Klima A, Steindl F, Palese P, Katinger H: Cross-neutralizing activity against divergent human immunodeficiency virus type 1 isolates induced by the gp41 sequence ELDKWAS. J Virol 1994;68:4031-4034.

- 38 Stiegler G, Kunert R, Purtscher M, Wolbank S, Voglauer R, Steindl F, Katinger H: A potent cross-clade neutralizing human monoclonal antibody against a novel epitope on gp41 of human immunodeficiency virus type 1 . AIDS Res Hum Retroviruses 2001;17:1757-1765.

39 Kong L, Lee JH, Doores KJ, Murin CD, Julien JP, McBride R, Liu Y, Marozsan A, Cupo A, Klasse PJ, Hoffenberg S, Caulfield M, King CR, Hua Y, Le KM, Khayat R, Deller MC, Clayton T, Tien H, Feizi T, Sanders RW, Paulson JC, Moore JP, Stanfield RL, Burton DR, Ward AB, Wilson IA: Supersite of immune vulnerability on the glycosylated face of HIV-1 envelope glycoprotein gp120. Nat Struct Mol Biol 2013;20: 796-803.

-40 Almond D, Kimura T, Kong X, Swetnam J, Zolla-Pazner S, Cardozo T: Structural conservation predominates over sequence variability in the crown of HIV type 1's V3 loop. AIDS Res Hum Retroviruses 2010;26:717-723.

-41 Hochleitner EO, Gorny MK, Zolla-Pazner S, Tomer KB: Mass spectrometric characterization of a discontinuous epitope of the HIV envelope protein HIV-gp120 recognized by the human monoclonal antibody 1331A. J Immunol 2000;164:4156-4161.

-42 Tomaras GD, Yates NL, Liu P, Qin L, Fouda GG, Chavez LL, Decamp AC, Parks RJ, Ashley VC, Lucas JT, Cohen M, Eron J, Hicks CB, Liao HX, Self SG, Landucci G, Forthal DN, Weinhold KJ, Keele BF, Hahn BH, Greenberg ML, Morris L, Karim SS, Blattner WA, Montefiori DC, Shaw GM, Perelson AS, Haynes BF: Initial B-cell responses to transmitted human immunodeficiency virus type 1 : virion-binding immunoglobulin $\mathrm{m}(\mathrm{IgM})$ and $\operatorname{IgG}$ antibodies followed by plasma anti-gp41 antibodies with ineffective control of initial viremia. J Virol 2008;82:12449-12463.

-43 Liu P, Overman RG, Yates NL, Alam SM, Vandergrift N, Chen Y, Graw F, Freel SA, Kappes JC, Ochsenbauer C, Montefiori DC, Gao F, Perelson AS, Cohen MS, Haynes BF, Tomaras GD: Dynamic antibody specificities and virion concentrations in circulating immune complexes in acute to chronic HIV-1 infection. J Virol 2011;85:11196-11207.

-44 Ogunniyi AO, Thomas BA, Politano TJ, Varadarajan N, Landais E, Poignard P, Walker BD, Kwon DS, Love JC: Profiling human antibody responses by integrated single-cell analysis. Vaccine 2014;32:2866-2873.

45 Banerjee K, Klasse PJ, Sanders RW, Pereyra F, Michael E, Lu M, Walker BD, Moore JP: IgG subclass profiles in infected HIV type 1 controllers and chronic progressors and in uninfected recipients of Env vaccines. AIDS Res Hum Retroviruses 2010;26:445-458.
Richardson MW, Mirchandani J, Duong J, Grimaldo S, Kocieda V, Hendel H, Khalili K, Zagury JF, Rappaport J: Antibodies to Tat and Vpr in the GRIV cohort: differential association with maintenance of long-term non-progression status in HIV-1 infection. Biomed Pharmacother 2003;57:4-14.

47 Broliden PA, Morfeldt-Mansson L, Rosen J, Jondal M, Wahren B: Fine specificity of IgG subclass response to group antigens in HIV 1-infected patients. Clin Exp Immunol 1989; 76:216-221.

48 Gallerano D, Ndlovu P, Makupe I, Focke-Tejkl M, Fauland K, Wollmann E, PuchhammerStockl E, Keller W, Sibanda E, Valenta R: Comparison of the specificities of IgG, IgG-subclass, IgA and IgM reactivities in African and European HIV-infected individuals with an HIV-1 clade C proteome-based array. PLoS One 2015;10:e0117204.

49 Yates NL, Stacey AR, Nolen TL, Vandergrift NA, Moody MA, Montefiori DC, Weinhold KJ, Blattner WA, Borrow P, Shattock R, Cohen MS, Haynes BF, Tomaras GD: HIV-1 gp41 envelope IgA is frequently elicited after transmission but has an initial short response half-life. Mucosal Immunol 2013;6:692-703.

50 Brown EP, Licht AF, Dugast AS, Choi I, BaileyKellogg C, Alter G, Ackerman ME: Highthroughput, multiplexed IgG subclassing of antigen-specific antibodies from clinical samples. J Immunol Methods 2012;386:117-123.

- 51 Mathiesen T, Broliden PA, Rosen J, Wahren B: Mapping of IgG subclass and T-cell epitopes on HIV proteins by synthetic peptides. Immunology 1989;67:453-459.

52 Gnann JW Jr, Nelson JA, Oldstone MB: Fine mapping of an immunodominant domain in the transmembrane glycoprotein of human immunodeficiency virus. J Virol 1987;61:2639-2641.

53 Kuehne Y, Reese G, Ballmer-Weber BK, Niggemann B, Hanschmann KM, Vieths S, Holzhauser T: A Novel multipeptide microarray for the specific and sensitive mapping of linear IgE-binding epitopes of food allergens. Int Arch Allergy Immunol 2015;166:213-224. 54 Gottardo R, Bailer RT, Korber BT, Gnanakaran S, Phillips J, Shen X, Tomaras GD, Turk E, Imholte G, Eckler L, Wenschuh H, Zerweck J, Greene K, Gao H, Berman PW, Francis D, Sinangil F, Lee C, Nitayaphan S, Rerks-Ngarm S, Kaewkungwal J, Pitisuttithum P, Tartaglia J, Robb ML, Michael NL, Kim JH, Zolla-Pazner S, Haynes BF, Mascola JR, Self S, Gilbert P, Montefiori DC: Plasma IgG to linear epitopes in the V2 and V3 regions of HIV-1 gp120 correlate with a reduced risk of infection in the RV144 vaccine efficacy trial. PLoS One 2013;8:e75665.

55 Moore PL, Gray ES, Choge IA, Ranchobe N, Mlisana K, Abdool Karim SS, Williamson C, Morris L: The C3-V4 region is a major target of autologous neutralizing antibodies in human immunodeficiency virus type 1 subtype $C$ infection. J Virol 2008;82:1860-1869.

56 McMichael AJ, Borrow P, Tomaras GD, Goonetilleke N, Haynes BF: The immune response during acute HIV-1 infection: clues for vaccine development. Nat Rev Immunol 2010; 10:11-23.
57 CDC Laboratories: Laboratory testing for the diagnosis of HIV infection: updated recommendations. http://stacks.cdc.gov/view/cdc/ 23447 (accessed August 27, 2014).

58 Richman DD, Wrin T, Little SJ, Petropoulos CJ: Rapid evolution of the neutralizing antibody response to HIV type 1 infection. Proc Natl Acad Sci USA 2003;100:4144-4149.

59 Gray ES, Moore PL, Choge IA, Decker JM, Bibollet-Ruche F, Li H, Leseka N, Treurnicht F, Mlisana K, Shaw GM, Karim SS, Williamson C, Morris L: Neutralizing antibody responses in acute human immunodeficiency virus type 1 subtype C infection. J Virol 2007;81:61876196.

60 Gray ES, Madiga MC, Moore PL, Mlisana K, Abdool Karim SS, Binley JM, Shaw GM, Mascola JR, Morris L: Broad neutralization of human immunodeficiency virus type 1 mediated by plasma antibodies against the gp41 membrane proximal external region. J Virol 2009; 83:11265-11274.

61 Doria-Rose NA, Klein RM, Daniels MG, O'Dell S, Nason M, Lapedes A, Bhattacharya T, Migueles SA, Wyatt RT, Korber BT, Mascola JR, Connors M: Breadth of human immunodeficiency virus-specific neutralizing activity in sera: clustering analysis and association with clinical variables. J Virol 2010;84:1631-1636.

62 Goo L, Chohan V, Nduati R, Overbaugh J: Early development of broadly neutralizing antibodies in HIV-1-infected infants. Nat Med 2014;20:655-658.

63 Lolli F, Colao MG, de Maio E, Di Pietro M, Galli E, Grippo A, Mazzotta F, Pinto F: Intrathecal synthesis of anti-HIV antibodies in AIDS patients. J Neurol Sci 1990;99:281-289.

64 Willoughby PB, Midgett JS, Folds JD: Antibody specificity for human immunodeficiency virus type 1 in serum and cerebrospinal fluid from patients with AIDS and AIDS-related complex. Eur J Clin Microbiol Infect Dis 1989; 8:1031-1037.

65 Mathiesen T, Sonnerborg A, Trojnar J, Wahren $B$ : Fine analysis of intrathecally synthesized anti-HIV IgG1-4 by peptide mapping. J Neurol Sci 1990;100:31-36.

66 Bachani M, Sacktor N, McArthur JC, Nath A, Rumbaugh J: Detection of anti-tat antibodies in CSF of individuals with HIV-associated neurocognitive disorders. J Neurovirol 2013; 19:82-88.

67 Cartry O, Moja P, Quesnel A, Pozzetto B, Lucht FR, Genin C: Quantification of IgA and IgG and specificities of antibodies to viral proteins in parotid saliva at different stages of HIV-1 infection. Clin Exp Immunol 1997;109: 47-53.

68 Toro MJ, Escalona L, Chaiyarit P, Warner NA, Gregory RL: Salivary immunoglobulin A antibodies to gp41 in human immunodeficiency virus-seropositive patients: lack of correlation with disease progression. Oral Microbiol Immunol 2001;16:188-192.

69 Skott P, Lucht E, Julander I, Dillner J, Bjorling E: Salivary sIgA response in HIV-1 infection. J Acquir Immune Defic Syndr 1999;21:73-80.
HIV-Specific Antibodies - Isotypes and Specificity
Int Arch Allergy Immunol 2015;167:223-241 DOI: $10.1159 / 000438484$ 
70 Belec L, Ghys PD, Hocini H, Nkengasong JN, Tranchot-Diallo J, Diallo MO, Ettiegne-Traore V, Maurice C, Becquart P, Matta M, Si-Mohamed A, Chomont N, Coulibaly IM, Wiktor SZ, Kazatchkine MD: Cervicovaginal secretory antibodies to human immunodeficiency virus type 1 (HIV-1) that block viral transcytosis through tight epithelial barriers in highly exposed HIV-1-seronegative African women. J Infect Dis 2001;184:1412-1422.

-71 Raux M, Finkielsztejn L, Salmon-Ceron D, Bouchez H, Excler JL, Dulioust E, Grouin JM, Sicard D, Blondeau C: IgG subclass distribution in serum and various mucosal fluids of HIV type 1-infected subjects. AIDS Res Hum Retroviruses 2000;16:583-594.

72 Wu X, Jackson S: Plasma and salivary IgG subclasses in HIV type 1 infection: evidence of both transudation and local synthesis of IgG in parotid saliva. AIDS Res Hum Retroviruses 2000;16:1423-1431.

-73 Wu X, Jackson S: A longitudinal study of plas$\mathrm{ma}$ and salivary antibodies in HIV-1 infection. Viral Immunol 2002;15:325-335.

-74 Emskoetter T, von Laer D, Veismann S, Ermer M: Human immunodeficiency virus (HIV)specific antibodies, neutralizing activity and antibody-dependent cellular cytotoxicity (ADCC) in the cerebrospinal fluid of HIV-infected patients. J Neuroimmunol 1989;24:61-66.

-75 von Gegerfelt A, Chiodi F, Keys B, Norkrans G, Hagberg L, Fenyo EM, Broliden K: Lack of autologous neutralizing antibodies in the cerebrospinal fluid of HIV-1 infected individuals. AIDS Res Hum Retroviruses 1992;8:1133-1138.

-76 Battle-Miller K, Eby CA, Landay AL, Cohen MH, Sha BE, Baum LL: Antibody-dependent cell-mediated cytotoxicity in cervical lavage fluids of human immunodeficiency virus type 1-infected women. J Infect Dis 2002;185:439447.

-77 Wei Q, Moldoveanu Z, Huang WQ, Alexander RC, Goepfert PA, Mestecky J: Comparative evaluation of HIV-1 neutralization in external secretions and sera of HIV-1-infected women. Open AIDS J 2012;6:293-302.

78 Roux KH, Taylor KA: AIDS virus envelope spike structure. Curr Opin Struct Biol 2007;17: 244-252.

79 Zolla-Pazner S, Cardozo T: Structure-function relationships of HIV-1 envelope sequencevariable regions refocus vaccine design. Nat Rev Immunol 2010;10:527-535.

80 Pancera M, McLellan JS, Wu X, Zhu J, Changela A, Schmidt SD, Yang Y, Zhou T, Phogat S, Mascola JR, Kwong PD: Crystal structure of PG16 and chimeric dissection with somatically related PG9: structure-function analysis of two quaternary-specific antibodies that effectively neutralize HIV-1. J Virol 2010;84:8098-8110.

-81 Pejchal R, Doores KJ, Walker LM, Khayat R, Huang PS, Wang SK, Stanfield RL, Julien JP, Ramos A, Crispin M, Depetris R, Katpally U, Marozsan A, Cupo A, Maloveste S, Liu Y, McBride R, Ito Y, Sanders RW, Ogohara C, Paulson JC, Feizi T, Scanlan CN, Wong CH, Moore JP, Olson WC, Ward AB, Poignard P, Schief WR, Burton DR, Wilson IA: A potent and broad neutralizing antibody recognizes and penetrates the HIV glycan shield. Science 2011; 334:1097-1103.

82 McLellan JS, Pancera M, Carrico C, Gorman J, Julien JP, Khayat R, Louder R, Pejchal R, Sastry M, Dai K, O'Dell S, Patel N, Shahzadul-Hussan S, Yang Y, Zhang B, Zhou T, Zhu J, Boyington JC, Chuang GY, Diwanji D, Georgiev I, Kwon YD, Lee D, Louder MK, Moquin S, Schmidt SD, Yang ZY, Bonsignori M, Crump JA, Kapiga SH, Sam NE, Haynes BF, Burton DR, Koff WC, Walker LM, Phogat S, Wyatt R, Orwenyo J, Wang LX, Arthos J, Bewley CA, Mascola JR, Nabel GJ, Schief WR, Ward AB, Wilson IA, Kwong PD: Structure of HIV-1 gp120 V1/V2 domain with broadly neutralizing antibody PG9. Nature 2011;480: 336-343.

83 Walker LM, Huber M, Doores KJ, Falkowska E, Pejchal R, Julien JP, Wang SK, Ramos A, Chan-Hui PY, Moyle M, Mitcham JL, Hammond PW, Olsen OA, Phung P, Fling S, Wong $\mathrm{CH}$, Phogat S, Wrin T, Simek MD, Koff WC, Wilson IA, Burton DR, Poignard P: Broad neutralization coverage of HIV by multiple highly potent antibodies. Nature 2011;477:466-470.

-84 Bonsignori M, Hwang KK, Chen X, Tsao CY, Morris L, Gray E, Marshall DJ, Crump JA, Kapiga SH, Sam NE, Sinangil F, Pancera M, Yongping Y, Zhang B, Zhu J, Kwong PD, O’Dell S, Mascola JR, Wu L, Nabel GJ, Phogat S, Seaman MS, Whitesides JF, Moody MA, Kelsoe G, Yang X, Sodroski J, Shaw GM, Montefiori DC, Kepler TB, Tomaras GD, Alam SM, Liao HX, Haynes BF: Analysis of a clonal lineage of HIV-1 envelope V2/V3 conformational epitope-specific broadly neutralizing antibodies and their inferred unmutated common ancestors. J Virol 2011;85:9998-10009.

85 Pantophlet R, Wrin T, Cavacini LA, Robinson JE, Burton DR: Neutralizing activity of antibodies to the V3 loop region of HIV-1 gp120 relative to their epitope fine specificity. Virology 2008;381:251-260.

- 86 Bell CH, Pantophlet R, Schiefner A, Cavacini LA, Stanfield RL, Burton DR, Wilson IA: Structure of antibody F425-B4e8 in complex with a $\mathrm{V} 3$ peptide reveals a new binding mode for HIV1 neutralization. J Mol Biol 2008;375:969-978.

87 Xu JY, Gorny MK, Palker T, Karwowska S, Zolla-Pazner S: Epitope mapping of two immunodominant domains of gp41, the transmembrane protein of human immunodeficiency virus type 1, using ten human monoclonal antibodies. J Virol 1991;65:4832-4838.

88 Frey G, Chen J, Rits-Volloch S, Freeman MM, Zolla-Pazner S, Chen B: Distinct conformational states of HIV-1 gp41 are recognized by neutralizing and non-neutralizing antibodies. Nat Struct Mol Biol 2010;17:1486-1491.

89 Julien JP, Sok D, Khayat R, Lee JH, Doores KJ, Walker LM, Ramos A, Diwanji DC, Pejchal R, Cupo A, Katpally U, Depetris RS, Stanfield RL, McBride R, Marozsan AJ, Paulson JC, Sanders RW, Moore JP, Burton DR, Poignard P, Ward $\mathrm{AB}$, Wilson IA: Broadly neutralizing antibody PGT121 allosterically modulates CD4 binding via recognition of the HIV-1 gp120 V3 base and multiple surrounding glycans. PLoS Pathog 2013;9:e1003342.
90 Scharf L, West AP Jr, Gao H, Lee T, Scheid JF, Nussenzweig MC, Bjorkman PJ, Diskin R: Structural basis for HIV-1 gp120 recognition by a germ-line version of a broadly neutralizing antibody. Proc Natl Acad Sci USA 2013; 110:6049-6054.

91 Kwong PD, Mascola JR, Nabel GJ: Broadly neutralizing antibodies and the search for an HIV-1 vaccine: the end of the beginning. Nat Rev Immunol 2013;13:693-701.

92 West AP Jr, Scharf L, Scheid JF, Klein F, Bjorkman PJ, Nussenzweig MC: Structural insights on the role of antibodies in HIV-1 vaccine and therapy. Cell 2014;156:633-648.

-93 Scharf L, Scheid JF, Lee JH, West AP Jr, Chen C, Gao H, Gnanapragasam PN, Mares R, Seaman MS, Ward AB, Nussenzweig MC, Bjorkman PJ: Antibody 8ANC195 reveals a site of broad vulnerability on the HIV-1 envelope spike. Cell Rep 2014;7:785-795.

94 Labrijn AF, Poignard P, Raja A, Zwick MB, Delgado K, Franti M, Binley J, Vivona V, Grundner C, Huang CC, Venturi M, Petropoulos CJ, Wrin T, Dimitrov DS, Robinson J, Kwong PD, Wyatt RT, Sodroski J, Burton DR: Access of antibody molecules to the conserved coreceptor binding site on glycoprotein gp120 is sterically restricted on primary human immunodeficiency virus type 1. J Virol 2003;77: 10557-10565.

95 Klein JS, Gnanapragasam PN, Galimidi RP, Foglesong CP, West AP Jr, Bjorkman PJ: Examination of the contributions of size and avidity to the neutralization mechanisms of the anti-HIV antibodies b12 and 4E10. Proc Natl Acad Sci USA 2009;106:7385-7390.

96 Kwong PD, Doyle ML, Casper DJ, Cicala C, Leavitt SA, Majeed S, Steenbeke TD, Venturi M, Chaiken I, Fung M, Katinger H, Parren PW, Robinson J, van Ryk D, Wang L, Burton DR, Freire E, Wyatt R, Sodroski J, Hendrickson WA, Arthos J: HIV-1 evades antibody-mediated neutralization through conformational masking of receptor-binding sites. Nature 2002;420:678-682.

97 van Gils MJ, Bunnik EM, Boeser-Nunnink BD, Burger JA, Terlouw-Klein M, Verwer N, Schuitemaker H: Longer V1V2 region with increased number of potential n-linked glycosylation sites in the HIV-1 envelope glycoprotein protects against HIV-specific neutralizing antibodies. J Virol 2011;85:6986-6995.

98 Moore PL, Gray ES, Wibmer CK, Bhiman JN, Nonyane M, Sheward DJ, Hermanus T, Bajimaya S, Tumba NL, Abrahams MR, Lambson BE, Ranchobe N, Ping L, Ngandu N, Abdool Karim Q, Abdool Karim SS, Swanstrom RI, Seaman MS, Williamson C, Morris L: Evolution of an HIV glycan-dependent broadly neutralizing antibody epitope through immune escape. Nat Med 2012;18:1688-1692.

-99 Scanlan CN, Pantophlet R, Wormald MR, Ollmann Saphire E, Stanfield R, Wilson IA, Katinger H, Dwek RA, Rudd PM, Burton DR: The broadly neutralizing anti-human immunodeficiency virus type 1 antibody 2 G12 recognizes a cluster of $\alpha 1 \rightarrow 2$ mannose residues on the outer face of gp120. J Virol 2002;76:73067321. 
100 Lavine CL, Lao S, Montefiori DC, Haynes BF, Sodroski JG, Yang X: High-mannose glycandependent epitopes are frequently targeted in broad neutralizing antibody responses during human immunodeficiency virus type 1 infection. J Virol 2012;86:2153-2164.

101 Liao HX, Lynch R, Zhou T, Gao F, Alam SM, Boyd SD, Fire AZ, Roskin KM, Schramm CA, Zhang Z, Zhu J, Shapiro L, Mullikin JC, Gnanakaran S, Hraber P, Wiehe K, Kelsoe G, Yang G, Xia SM, Montefiori DC, Parks R, Lloyd KE, Scearce RM, Soderberg KA, Cohen M, Kamanga G, Louder MK, Tran LM, Chen Y, Cai F, Chen S, Moquin S, Du X, Joyce MG, Srivatsan S, Zhang B, Zheng A, Shaw GM, Hahn BH, Kepler TB, Korber BT, Kwong PD, Mascola JR, Haynes BF: Co-evolution of a broadly neutralizing HIV-1 antibody and founder virus. Nature 2013;496:469-476.

-102 Cardoso RM, Zwick MB, Stanfield RL, Kunert R, Binley JM, Katinger H, Burton DR, Wilson IA: Broadly neutralizing anti-HIV antibody 4E10 recognizes a helical conformation of a highly conserved fusion-associated motif in gp41. Immunity 2005;22:163-173.

103 West AP Jr, Diskin R, Nussenzweig MC, Bjorkman PJ: Structural basis for germ-line gene usage of a potent class of antibodies targeting the CD4-binding site of HIV-1 gp120. Proc Natl Acad Sci USA 2012;109:E2083E2090.

104 Klein F, Diskin R, Scheid JF, Gaebler C, Mouquet $\mathrm{H}$, Georgiev IS, Pancera M, Zhou T, Incesu RB, Fu BZ, Gnanapragasam PN, Oliveira TY, Seaman MS, Kwong PD, Bjorkman PJ, Nussenzweig MC: Somatic mutations of the immunoglobulin framework are generally required for broad and potent HIV-1 neutralization. Cell 2013;153:126-138.

105 Georgiev IS, Doria-Rose NA, Zhou T, Kwon YD, Staupe RP, Moquin S, Chuang GY, Louder MK, Schmidt SD, Altae-Tran HR, Bailer RT, McKee K, Nason M, O’Dell S, Ofek G, Pancera M, Srivatsan S, Shapiro L, Connors M, Migueles SA, Morris L, Nishimura Y, Martin MA, Mascola JR, Kwong PD: Delineating antibody recognition in polyclonal sera from patterns of HIV-1 isolate neutralization. Science 2013;340:751-756.

106 Medina-Ramirez M, Sanchez-Merino V, Sanchez-Palomino S, Merino-Mansilla A, Ferreira CB, Perez I, Gonzalez N, Alvarez A, Alcocer-Gonzalez JM, Garcia F, Gatell JM, Alcami J, Yuste E: Broadly cross-neutralizing antibodies in HIV-1 patients with undetectable viremia. J Virol 2011;85:5804-5813.

107 Simek MD, Rida W, Priddy FH, Pung P, Carrow E, Laufer DS, Lehrman JK, Boaz M, Tarragona-Fiol T, Miiro G, Birungi J, Pozniak A, McPhee DA, Manigart O, Karita E, Inwoley A, Jaoko W, Dehovitz J, Bekker LG, Pitisuttithum P, Paris R, Walker LM, Poignard P, Wrin T, Fast PE, Burton DR, Koff WC: $\mathrm{Hu}-$ man immunodeficiency virus type 1 elite neutralizers: individuals with broad and potent neutralizing activity identified by using a high-throughput neutralization assay together with an analytical selection algorithm. J Virol 2009;83:7337-7348.
108 Li Y, Migueles SA, Welcher B, Svehla K, Phogat A, Louder MK, Wu X, Shaw GM, Connors M, Wyatt RT, Mascola JR: Broad HIV-1 neutralization mediated by CD4-binding site antibodies. Nat Med 2007;13:1032-1034.

109 Loomis-Price LD, Cox JH, Mascola JR, VanCott TC, Michael NL, Fouts TR, Redfield RR, Robb ML, Wahren B, Sheppard HW, Birx DL: Correlation between humoral responses to human immunodeficiency virus type 1 envelope and disease progression in early-stage infection. J Infect Dis 1998;178:1306-1316.

-110 Palker TJ, Matthews TJ, Clark ME, Cianciolo GJ, Randall RR, Langlois AJ, White GC, Safai B, Snyderman R, Bolognesi DP, et al: A conserved region at the $\mathrm{COOH}$ terminus of human immunodeficiency virus gp120 envelope protein contains an immunodominant epitope. Proc Natl Acad Sci USA 1987;84: 2479-2483.

-111 Warren RQ, Nkya WM, Shao JF, Anderson SA, Wolf H, Hendrix CW, Kanda P, Wabuke M, Boswell RN, Redfield RR, et al: Comparison of antibody reactivity to human immunodeficiency virus type 1 (HIV-1) gp160 epitopes in sera from HIV-1-infected individuals from Tanzania and from the United States. J Clin Microbiol 1992;30:126-131.

-112 Chiodi F, Mathiesen T, Albert J, Parks E, Norrby $\mathrm{E}$, Wahren $\mathrm{B}$ : IgG subclass responses to a transmembrane protein (gp41) peptide in HIV infection. J Immunol 1989;142:3809-3814.

113 Klasse PJ, Blomberg J, Pipkorn R: Differential IgG subclass responses to epitopes in transmembrane protein of HIV-1. Viral Immunol 1990;3:89-98.

114 Klasse PJ, Pipkorn R, Blomberg J: Presence of antibodies to a putatively immunosuppressive part of human immunodeficiency virus (HIV) envelope glycoprotein gp41 is strongly associated with health among HIV-positive subjects. Proc Natl Acad Sci USA 1988;85: 5225-5229.

115 Gnann JW Jr, Nelson JA, Oldstone MB: Fine mapping of an immunodominant domain in the transmembrane glycoprotein of human immunodeficiency virus. J Virol 1987;61: 2639-2641.

116 Vieillard V, Costagliola D, Simon A, Debré P: Specific adaptive humoral response against a gp41 motif inhibits CD4 T-cell sensitivity to NK lysis during HIV-1 infection. AIDS 2006;20:1795-1804.

117 Zheng B, Wang K, Lu L, Yu F, Cheng M, Jiang S, Liu K, Cai L: Hydrophobic mutations in buried polar residues enhance HIV-1 gp41 $\mathrm{N}$-terminal heptad repeat-C-terminal heptad repeat interactions and C-peptides' anti-HIV activity. AIDS 2014;28:1251-1260.

118 Sackett K, Shai Y: The HIV-1 gp41 N-terminal heptad repeat plays an essential role in membrane fusion. Biochemistry 2002;41: 4678-4685.

119 Weiss CD: HIV-1 gp41: mediator of fusion and target for inhibition. AIDS Rev 2003;5: 214-221.
120 Haffar OK, Dowbenko DJ, Berman PW Topogenic analysis of the human immunodeficiency virus type 1 envelope glycoprotein, gp160, in microsomal membranes. J Cell Biol 1988; 107:1677-1687.

121 Postler TS, Desrosiers RC: The tale of the long tail: the cytoplasmic domain of HIV-1 gp41. J Virol 2013;87:2-15.

122 Zwick MB, Jensen R, Church S, Wang M, Stiegler G, Kunert R, Katinger H, Burton DR: Anti-human immunodeficiency virus type 1 (HIV-1) antibodies 2F5 and 4E10 require surprisingly few crucial residues in the membrane-proximal external region of glycoprotein gp41 to neutralize HIV-1. J Virol 2005 79:1252-1261.

123 Nelson JD, Brunel FM, Jensen R, Crooks ET, Cardoso RM, Wang M, Hessell A, Wilson IA, Binley JM, Dawson PE, Burton DR, Zwick MB: An affinity-enhanced neutralizing antibody against the membrane-proximal external region of human immunodeficiency virus type 1 gp41 recognizes an epitope between those of 2F5 and 4E10. J Virol 2007;81:40334043.

124 Binley JM, Lybarger EA, Crooks ET, Seaman MS, Gray E, Davis KL, Decker JM, Wycuff D, Harris L, Hawkins N, Wood B, Nathe C, Richman D, Tomaras GD, Bibollet-Ruche F, Robinson JE, Morris L, Shaw GM, Montefiori DC, Mascola JR: Profiling the specificity of neutralizing antibodies in a large panel of plasmas from patients chronically infected with human immunodeficiency virus type 1 subtypes B and C. J Virol 2008;82:1165111668.

125 Khalife J, Guy B, Capron M, Kieny MP, Ameisen JC, Montagnier L, Lecocq JP, Capron A: Isotypic restriction of the antibody response to human immunodeficiency virus. AIDS Res Hum Retroviruses 1988;4: 3-9.

126 Yates NL, Lucas JT, Nolen TL, Vandergrift NA, Soderberg KA, Seaton KE, Denny TN, Haynes BF, Cohen MS, Tomaras GD: Multiple HIV-1-specific IgG3 responses decline during acute HIV-1: implications for detection of incident HIV infection. AIDS 2011;25: 2089-2097.

127 Lambotte O, Ferrari G, Moog C, Yates NL, Liao HX, Parks RJ, Hicks CB, Owzar K, Tomaras GD, Montefiori DC, Haynes BF, Delfraissy JF: Heterogeneous neutralizing antibody and antibody-dependent cell cytotoxicity responses in HIV-1 elite controllers. AIDS 2009;23:897-906.

128 Lal RB, Heiba IM, Dhawan RR, Smith ES, Perine PL: IgG subclass responses to human immunodeficiency virus-1 antigens: lack of IgG2 response to gp41 correlates with clinical manifestation of disease. Clin Immunol Immunopathol 1991;58:267-277.

129 Ngo-Giang-Huong N, Candotti D, Goubar A, Autran B, Maynart M, Sicard D, Clauvel JP, Agut H, Costagliola D, Rouzioux C: HIV type 1-specific IgG2 antibodies: markers of helper T cell type 1 response and prognostic marker of long-term nonprogression. AIDS Res Hum Retroviruses 2001;17:1435-1446. 
130 Martinez V, Costagliola D, Bonduelle O, N'go $\mathrm{N}$, Schnuriger A, Theodorou I, Clauvel JP, Sicard D, Agut H, Debré P, Rouzioux C, Autran B: Combination of HIV-1-specific CD4 Th1 cell responses and IgG2 antibodies is the best predictor for persistence of long-term nonprogression. J Infect Dis 2005; 191:2053-2063.

131 Jefferis R, Lund J: Interaction sites on human IgG-Fc for Fc $\gamma$ R: current models. Immunol Lett 2002;82:57-65.

132 Ikuta K, Morita C, Miyake S, Ito T, Okabayashi M, Sano K, Nakai M, Hirai K, Kato S: Expression of human immunodeficiency virus type 1 (HIV-1) gag antigens on the surface of a cell line persistently infected with HIV-1 that highly expresses HIV-1 antigens. Virology 1989;170:408-417.

133 Laurent AG, Krust B, Rey MA, Montagnier L, Hovanessian AG: Cell surface expression of several species of human immunodeficiency virus type 1 major core protein. J Virol 1989; 63:4074-4078.

134 Kaminchik J, Bashan N, Itach A, Sarver N, Gorecki M, Panet A: Genetic characterization of human immunodeficiency virus type 1 nef gene products translated in vitro and expressed in mammalian cells. J Virol 1991;65: 583-588.

135 Debaisieux S, Rayne F, Yezid H, Beaumelle B: The ins and outs of HIV-1 Tat. Traffic 2012; 13:355-363.

136 Dube M, Bego MG, Paquay C, Cohen EA: Modulation of HIV-1-host interaction: role of the Vpu accessory protein. Retrovirology 2010;7:114.

-137 Andrieu JM, Eme D, Venet A, Audroin C, Tourani JM, Stern M, Israel-Biet D, Beldjord K, Driss F, Even P: Serum HIV antigen and anti-p24-antibodies in 200 HIV seropositive patients: correlation with CD4 and CD8 lymphocyte subsets. Clin Exp Immunol 1988;73: $1-5$.

138 Ellaurie M, Rubinstein A: Correlation of serum antigen and antibody concentration with clinical features in HIV infection. Arch Dis Child 1991;66:200-203.

139 Lenassi M, Cagney G, Liao M, Vaupotic T, Bartholomeeusen K, Cheng Y, Krogan NJ, Plemenitas A, Peterlin BM: HIV nef is secreted in exosomes and triggers apoptosis in bystander $\mathrm{CD}^{+}{ }^{+} \mathrm{T}$ cells. Traffic 2010;11:110122.

140 Ferrucci A, Nonnemacher MR, Wigdahl B: Human immunodeficiency virus viral protein $\mathrm{R}$ as an extracellular protein in neuropathogenesis. Adv Virus Res 2011;81:165199.

141 Chun TW, Moir S, Fauci AS: HIV reservoirs as obstacles and opportunities for an HIV cure. Nat Immunol. 2015;16:584-589.

142 Citro A, Barnaba V, Martini H: From T cell apoptosis to chronic immune activation in inflammatory diseases. Int Arch Allergy Immunol 2014;164:140-146.

- 143 DeVico AL, Veronese FD, Lee SL, Gallo RC, Sarngadharan MG: High prevalence of serum antibodies to reverse transcriptase in HIV1-infected individuals. AIDS Res Hum Retroviruses 1988;4:17-22.
144 Janvier B, Mallet F, Cheynet V, Dalbon P, Vernet G, Besnier JM, Choutet P, Goudeau A, Mandrand B, Barin F: Prevalence and persistence of antibody titers to recombinant HIV1 core and matrix proteins in HIV-1 infection. J Acquir Immune Defic Syndr 1993;6: 898-903.

145 Jiang JD, Chu FN, Naylor PH, Kirkley JE, Mandeli J, Wallace JI, Sarin PS, Goldstein AL, Holland JF, Bekesi JG: Specific antibody responses to synthetic peptides of HIV-1 p17 correlate with different stages of HIV-1 infection. J Acquir Immune Defic Syndr 1992;5:382-390.

146 Burbelo PD, Bayat A, Rhodes CS, Hoh R, Martin JN, Fromentin R, Chomont N, Hutter G, Kovacs JA, Deeks SG: HIV antibody characterization as a method to quantify reservoir size during curative interventions. J Infect Dis 2014;209:1613-1617.

147 Re MC, Vignoli M, Furlini G, Gibellini D, Colangeli V, Vitone F, La Placa M: Antibodies against full-length Tat protein and some lowmolecular-weight Tat-peptides correlate with low or undetectable viral load in HIV-1 seropositive patients. J Clin Virol 2001;21:81-89.

148 Rezza G, Fiorelli V, Dorrucci M, Ciccozzi M, Tripiciano A, Scoglio A, Collacchi B, Ruiz-Alvarez M, Giannetto C, Caputo A, Tomasoni L, Castelli F, Sciandra M, Sinicco A, Ensoli F, Butto S, Ensoli B: The presence of anti-Tat antibodies is predictive of long-term nonprogression to AIDS or severe immunodeficiency: findings in a cohort of HIV-1 seroconverters. J Infect Dis 2005;191:1321-1324.

149 Rodman TC, Pruslin FH, To SE, Winston R: Human immunodeficiency virus (HIV) Tatreactive antibodies present in normal HIVnegative sera and depleted in HIV-positive sera: identification of the epitope. J Exp Med 1992;175:1247-1253.

150 Reiss P, de Ronde A, Lange JM, de Wolf F, Dekker J, Danner SA, Debouck C, Goudsmit J: Low antigenicity of HIV-1 rev: rev-specific antibody response of limited value as correlate of rev gene expression and disease progression. AIDS Res Hum Retroviruses 1989; 5:621-628.

151 Tahtinen M, Ranki A, Valle SL, Ovod V, Krohn K: B-cell epitopes in HIV-1 Tat and Rev proteins colocalize with T-cell epitopes and with functional domains. Biomed Pharmacother 1997;51:480-487.

152 Reiss P, de Wolf F, Kuiken CL, de Ronde A, Dekker J, Boucher CA, Debouck C, Lange JM, Goudsmit J: Contribution of antibody response to recombinant HIV-1 gene-encoded products nef, rev, tat, and protease in predicting development of AIDS in HIV-1-infected individuals. J Acquir Immune Defic Syndr 1991;4:165-172.

153 Wieland U, Kratschmann H, Kehm R, Kuhn JE, Naher H, Kramer MD, Braun RW: Antigenic domains of the HIV-1 vif protein as recognized by human sera and murine monoclonal antibodies. AIDS Res Hum Retroviruses 1991;7:861-867.

154 Schwander S, Braun RW, Kuhn JE, Hufert FT, Kern P, Dietrich M, Wieland U: Prevalence of antibodies to recombinant virion in- fectivity factor in the sera of prospectively studied patients with HIV-1 infection. J Med Virol 1992;36:142-146.

155 Reiss P, Lange JM, de Ronde A, de Wolf F, Dekker J, Danner SA, Debouck C, Goudsmit $\mathrm{J}$ : Antibody response to viral proteins $\mathrm{U}(\mathrm{vpu})$ and R (vpr) in HIV-1-infected individuals. J Acquir Immune Defic Syndr 1990;3:115-122.

156 Chen YM, Rey WY, Lan YC, Lai SF, Huang YC, Wu SI, Liu TT, Hsiao KJ: Antibody reactivity to HIV-1 Vpu in HIV-1/AIDS patients on highly active antiretroviral therapy. J Biomed Sci 2003;10:266-275.

157 Schneider T, Hildebrandt P, Ronspeck W, Weigelt W, Pauli G: The antibody response to the HIV-1 specific 'out' (vpu) protein: identification of an immunodominant epitope and correlation of antibody detectability to clinical stages. AIDS Res Hum Retroviruses 1990 6:943-950.

158 Corro G, Crudeli CM, Rocco CA, Marino SA, Sen L: High levels of anti-Nef antibodies may prevent AIDS disease progression in vertically HIV-1-infected infants. J Int AIDS Soc 2014;17:18790.

159 Xu W, Santini PA, Sullivan JS, He B, Shan M, Ball SC, Dyer WB, Ketas TJ, Chadburn A, Cohen-Gould L, Knowles DM, Chiu A, Sanders RW, Chen K, Cerutti A: HIV-1 evades virusspecific IgG2 and IgA responses by targeting systemic and intestinal B cells via long-range intercellular conduits. Nat Immunol 2009;10: 1008-1017.

160 Boucher CA, de Jager MH, Debouck C, Epstein LG, de Wolf F, Wolfs TF, Goudsmit J: Antibody response to human immunodeficiency virus type 1 protease according to risk group and disease stage. J Clin Microbiol 1989;27:1577-1581.

161 Chan DC, Fass D, Berger JM, Kim PS: Core structure of gp41 from the HIV envelope glycoprotein. Cell 1997;89:263-273.

162 Rizzuto CD, Wyatt R, Hernandez-Ramos N, Sun Y, Kwong PD, Hendrickson WA, Sodroski J: A conserved HIV gp120 glycoprotein structure involved in chemokine receptor binding. Science 1998;280:1949-1953.

163 Zhou T, Zhu J, Wu X, Moquin S, Zhang B, Acharya P, Georgiev IS, Altae-Tran HR, Chuang GY, Joyce MG, Do Kwon Y, Longo NS, Louder MK, Luongo T, McKee K, Schramm CA, Skinner J, Yang Y, Yang Z, Zhang Z, Zheng A, Bonsignori M, Haynes BF Scheid JF, Nussenzweig MC, Simek M, Burton DR, Koff WC, Mullikin JC, Connors M, Shapiro L, Nabel GJ, Mascola JR, Kwong PD: Multidonor analysis reveals structural elements, genetic determinants, and maturation pathway for HIV-1 neutralization by VRC01class antibodies. Immunity 2013;39:245-258

164 Scheid JF, Mouquet H, Ueberheide B, Diskin R, Klein F, Oliveira TY, Pietzsch J, Fenyo D, Abadir A, Velinzon K, Hurley A, Myung S, Boulad F, Poignard P, Burton DR, Pereyra F, Ho DD, Walker BD, Seaman MS, Bjorkman PJ, Chait BT, Nussenzweig MC: Sequence and structural convergence of broad and potent HIV antibodies that mimic CD4 binding. Science 2011;333:1633-1637. 
165 Cimbro R, Gallant TR, Dolan MA, Guzzo C, Zhang P, Lin Y, Miao H, van Ryk D, Arthos J, Gorshkova I, Brown PH, Hurt DE, Lusso P: Tyrosine sulfation in the second variable loop (V2) of HIV-1 gp120 stabilizes V2-V3 interaction and modulates neutralization sensitivity. Proc Natl Acad Sci USA 2014;111:31523157.

166 Liao H, Guo JT, Lange MD, Fan R, Zemlin M, Su K, Guan Y, Zhang Z: Contribution of $\mathrm{V}_{\mathrm{H}}$ replacement products to the generation of anti-HIV antibodies. Clin Immunol 2013; 146:46-55.

167 Gorny MK, Wang XH, Williams C, Volsky B, Revesz K, Witover B, Burda S, Urbanski M, Nyambi P, Krachmarov C, Pinter A, ZollaPazner S, Nadas A: Preferential use of the VH5-51 gene segment by the human immune response to code for antibodies against the V3 domain of HIV-1. Mol Immunol 2009; 46:917-926.

168 Doria-Rose NA, Georgiev I, O’Dell S, Chuang GY, Staupe RP, McLellan JS, Gorman J, Pancera $\mathrm{M}$, Bonsignori $\mathrm{M}$, Haynes $\mathrm{BF}$, Burton DR, Koff WC, Kwong PD, Mascola JR: A short segment of the HIV-1 gp120 V1/V2 region is a major determinant of resistance to V1/V2 neutralizing antibodies. J Virol 2012; 86:8319-8323.

-169 Alsmadi O, Herz R, Murphy E, Pinter A, Tilley SA: A novel antibody-dependent cellular cytotoxicity epitope in gp120 is identified by two monoclonal antibodies isolated from a long-term survivor of human immunodeficiency virus type 1 infection. J Virol 1997;71: 925-933.

170 Zolla-Pazner S, O’Leary J, Burda S, Gorny MK, Kim M, Mascola J, McCutchan F: Serotyping of primary human immunodeficiency virus type 1 isolates from diverse geographic locations by flow cytometry. J Virol 1995;69: 3807-3815.

171 Buchacher A, Predl R, Strutzenberger K, Steinfellner W, Trkola A, Purtscher M, Gruber G, Tauer C, Steindl F, Jungbauer A, et al: Generation of human monoclonal antibodies against HIV-1 proteins; electrofusion and Epstein-Barr virus transformation for peripheral blood lymphocyte immortalization. AIDS Res Hum Retroviruses 1994;10:359369.

172 Gorny MK, Gianakakos V, Sharpe S, ZollaPazner S: Generation of human monoclonal antibodies to human immunodeficiency virus. Proc Natl Acad Sci USA 1989;86:16241628.
173 Trkola A, Pomales AB, Yuan H, Korber B, Maddon PJ, Allaway GP, Katinger H, Barbas CF 3rd, Burton DR, Ho DD, et al: Cross-clade neutralization of primary isolates of human immunodeficiency virus type 1 by human monoclonal antibodies and tetrameric CD4IgG. J Virol 1995;69:6609-6617.

174 Huang J, Ofek G, Laub L, Louder MK, DoriaRose NA, Longo NS, Imamichi H, Bailer RT, Chakrabarti B, Sharma SK, Alam SM, Wang T, Yang Y, Zhang B, Migueles SA, Wyatt R, Haynes BF, Kwong PD, Mascola JR, Connors M: Broad and potent neutralization of HIV-1 by a gp41-specific human antibody. Nature 2012;491:406-412.

175 Reardon PN, Sage H, Dennison SM, Martin JW, Donald BR, Alam SM, Haynes BF, Spicer LD: Structure of an HIV-1-neutralizing antibody target, the lipid-bound gp41 envelope membrane proximal region trimer. Proc Natl Acad Sci USA 2014;111:1391-1396.

176 Pejchal R, Gach JS, Brunel FM, Cardoso RM, Stanfield RL, Dawson PE, Burton DR, Zwick $\mathrm{MB}$, Wilson IA: A conformational switch in human immunodeficiency virus gp41 revealed by the structures of overlapping epitopes recognized by neutralizing antibodies. J Virol 2009;83:8451-8462.

177 Frey G, Peng H, Rits-Volloch S, Morelli M, Cheng Y, Chen B: A fusion-intermediate state of HIV-1 gp41 targeted by broadly neutralizing antibodies. Proc Natl Acad Sci USA 2008;105:3739-3744.

178 Yang G, Holl TM, Liu Y, Li Y, Lu X, Nicely NI, Kepler TB, Alam SM, Liao HX, Cain DW, Spicer L, VandeBerg JL, Haynes BF, Kelsoe G: Identification of autoantigens recognized by the $2 \mathrm{~F} 5$ and $4 \mathrm{E} 10$ broadly neutralizing HIV-1 antibodies. J Exp Med 2013;210:241-256.

179 Haynes BF, Fleming J, St Clair EW, Katinger H, Stiegler G, Kunert R, Robinson J, Scearce RM, Plonk K, Staats HF, Ortel TL, Liao HX, Alam SM: Cardiolipin polyspecific autoreactivity in two broadly neutralizing HIV-1 antibodies. Science 2005;308:1906-1908.

180 Alam SM, Scearce RM, Parks RJ, Plonk K, Plonk SG, Sutherland LL, Gorny MK, ZollaPazner S, Vanleeuwen S, Moody MA, Xia SM, Montefiori DC, Tomaras GD, Weinhold KJ, Karim SA, Hicks CB, Liao HX, Robinson J, Shaw GM, Haynes BF: Human immunodeficiency virus type 1 gp41 antibodies that mask membrane proximal region epitopes: antibody binding kinetics, induction, and potential for regulation in acute infection. J Virol 2008;82:115-125.
181 Alam SM, McAdams M, Boren D, Rak M, Scearce RM, Gao F, Camacho ZT, Gewirth D, Kelsoe G, Chen P, Haynes BF: The role of antibody polyspecificity and lipid reactivity in binding of broadly neutralizing anti-HIV-1 envelope human monoclonal antibodies $2 \mathrm{~F} 5$ and 4E10 to glycoprotein 41 membrane proximal envelope epitopes. J Immunol 2007;178: 4424-4435.

182 Eron JJ, Benoit SL, Jemsek J, MacArthur RD, Santana J, Quinn JB, Kuritzkes DR, Fallon MA, Rubin M: Treatment with lamivudine, zidovudine, or both in HIV-positive patients with 200 to $500 \mathrm{CD} 4+$ cells per cubic millimeter. N Engl J Med 1995;333:1662-1669.

183 Hammer SM, Squires KE, Hughes MD, Grimes JM, Demeter LM, Currier JS, Eron JJ Jr, Feinberg JE, Balfour HH Jr, Deyton LR, Chodakewitz JA, Fischl MA: A controlled trial of two nucleoside analogues plus indinavir in persons with human immunodeficiency virus infection and CD 4 cell counts of 200 per cubic millimeter or less. N Engl J Med 1997; 337:725-733.

184 Gulick RM, Mellors JW, Havlir D, Eron JJ, Gonzalez C, McMahon D, Richman DD, Valentine FT, Jonas L, Meibohm A, Emini EA, Chodakewitz JA: Treatment with indinavir, zidovudine, and lamivudine in adults with human immunodeficiency virus infection and prior antiretroviral therapy. N Engl J Med 1997;337:734-739.

185 Liu J, Bartesaghi A, Borgnia MJ, Sapiro G, Subramaniam S: Molecular architecture of native HIV-1 gp120 trimers. Nature 2008; 455:109-113.

186 Bartesaghi A, Merk A, Borgnia MJ, Milne JL, Subramaniam S: Prefusion structure of trimeric HIV-1 envelope glycoprotein determined by cryo-electron microscopy. Nat Struct Mol Biol 2013;20:1352-1357.

187 Xiao X, Chen W, Feng Y, Dimitrov DS: Maturation pathways of cross-reactive HIV-1 neutralizing antibodies. Viruses 2009;1:802817.

188 Shingai M, Donau OK, Plishka RJ, BucklerWhite A, Mascola JR, Nabel GJ, Nason MC, Montefiori D, Moldt B, Poignard P, Diskin R, Bjorkman PJ, Eckhaus MA, Klein F, Mouquet H, Cetrulo Lorenzi JC, Gazumyan A, Burton DR, Nussenzweig MC, Martin MA, Nishimura Y: Passive transfer of modest titers of potent and broadly neutralizing anti-HIV monoclonal antibodies block SHIV infection in macaques. J Exp Med 2014;211:20612074. 